\title{
ESSENTIAL METALLOELEMENT CHELATES FACILITATE REPAIR OF RADIATION INJURY
}

\author{
John R. J. Sorenson* ${ }^{* 1 a}$, Lee S. F. Soderberg ${ }^{1 b}$, Louis W. Chang ${ }^{2}$, and Richard B. Walker ${ }^{3}$ \\ ${ }^{1}$ University of Arkansas, Medical Sciences Campus, Little Rock, Arkansas 72205, USA \\ ${ }^{a}$ Division of Medicinal Chemistry, Department of Pharmaceutical Sciences, College of Pharmacy \\ <sorensonjohnrj@uams.edu> b Department of Microbiology and Immunology, College of Medicine \\ ${ }^{2}$ National Health Research Institutes, Division of Environmental Health and Occupational Medicine Taiwan, \\ Republic of China, \\ ${ }^{3}$ University of Arkansas at Pine Bluff, Department of Chemistry and Physics \\ Pine Bluff, Arkansas 71611, USA
}

\begin{abstract}
Treatment with essential metalloelement $(\mathrm{Cu}, \mathrm{Fe}, \mathrm{Mn}$, and $\mathrm{Zn})$ chelates or combinations of them before and/or after radiation injury is a useful approach to overcoming radiation injury. No other agents are known to increase survival when they are used to treat after irradiation, in a radiorecovery treatment paradigm. These chelates may be useful in facilitating de novo syntheses of essential metalloelement-dependent enzymes required to repair radiation injury. Reports of radioprotection, which involves treatment before irradiation, with calcium-channel blockers, acyl Melatonin homologs, and substituted anilines, which may serve as chelating agents after biochemical modification in vivo, as well as Curcumin, which is a chelating agent, have been included in this review. These inclusions are intended to suggest additional approaches to combination treatments that may be useful in facilitating radiation recovery. These approaches to radioprotection and radiorecovery offer promise in facilitating recovery from radiation-induced injury experienced by patients undergoing radiotherapy for neoplastic disease and by individuals who experience environmental, occupational, or accidental exposure to ultraviolet, $x$-ray, or $\gamma$-ray radiation. Since there are no existing treatments of radiation-injury intended to facilitate tissue repair, studies of essential metalloelement chelates and combinations of them, as well as combinations of them with existing organic radioprotectants, seem worthwhile.
\end{abstract}

\section{INTRODUCTION}

\section{Essentiality and Speciation of $\mathrm{Cu}, \mathrm{Fe}, \mathrm{Mn}$, and $\mathrm{Zn}$ In Vivo}

Copper, iron, manganese, and zinc are essential metalloelements like sodium, potassium, calcium, magnesium, chromium, cobalt, and vanadium. These essential metalloelements as well as essential amino acids, essential fatty acids, and essential cofactors (vitamins) are required by all cells for normal metabolic processes but cannot be synthesized de novo and dietary intake and absorption are required to obtain them. Amounts of $\mathrm{Cu}, \mathrm{Fe}, \mathrm{Mn}$, and $\mathrm{Zn}$ found in body tissues and fluids [1,2] correlate with the number and kind of metabolic processes requiring them. However, there may be decreases in tissue content due to inadequate dietary intake and absorption associated with soil depletion, socioeconomic circumstances, and aging-related declines in consumption.

Ionic forms of these metalloelements have particularly high affinities for organic ligands found in biological systems and rapidly undergo bonding interactions to form complexes or chelates in biological systems. Calculated amounts of ionic $\mathrm{Cu}\left(10^{-18} \mathrm{M}\right)$, Fe $\left(10^{-23} \mathrm{M}\right), \mathrm{Mn}\left(10^{-12} \mathrm{M}\right)$, and $\mathrm{Zn}\left(10^{-9} \mathrm{M}\right)$ in plasma [3] are extremely small and not measurable with existing equipment. Concentrations of these ionically bonded essential metalloelements are likely to be even smaller in solid tissues, which contain many more bonding ligands. Consequently, measured tissue $\mathrm{Cu}, \mathrm{Fe}, \mathrm{Mn}$, and $\mathrm{Zn}$ contents reflect tissue contents of chelates. These are primarily metalloelement-dependent enzymes (Table 1), proteins such as Hemoglobin, Ferritin, Metallothioneines (MTs), $\boldsymbol{\beta}_{2}$-Macroglobulins, and Transferrin, as well as RNA and DNA chelates, small molecular mass amino acid, carboxylic acid, phosphate, amine, diamine, and thiol chelates and various small molecular mass peptide chelates [4 and cited refs.]. Ionically bonded metalloelement compounds will immediately form coordinate-covalent bonded chelates in biological systems as a result of bonding interactions with components of these systems capable of these bonding interactions. To study effects of essential 
metalloelements in a biological system it is most inappropriate to use ionically bonded forms of a particular metalloelement and most appropriate to use relevant chelates, which have particularly important roles in mediating biochemical repair of radiation injury via ligand exchange processes.

Table I. Established and recently suggested $\mathrm{Cu}, \mathrm{Fe}, \mathrm{Mn}$, and $\mathrm{Zn}$ dependent mammalian enzymes.

Cu-dependent enzymes [4-19]

Cytochrome c Oxidase

Extracellular and Cytosolic

$\mathrm{Cu}$-Dependent and $\mathrm{Zn}$-Modulated

Superoxide Dismutases $\left(\mathrm{Cu}_{2} \mathrm{Zn}_{2} \mathrm{SOD}\right)$

Tyrosinase

Dopamine- $\beta$-Mono-Oxygenase

Neurocuprein

Amine Oxidases

Factors V and VIII

Ceruloplasmin

$\alpha$-Amidating Mono-Oxygenases

Procollagen and Proelastin

Peptidyllysyl Oxidases

Prion Protein

Methionine Synthase

Amyloid Precursor Protein

Plasma Pituitary Adenylate Cyclase-Activating

Polypeptide

\section{CCS}

Other possible $\mathrm{Cu}$-dependent enzymes [20-24]

Adenylate Cyclase

Guanylate Cyclase

Lipolytic Protein

ACE1 and CUP2

Iron-dependent enzymes [5,25]

Electron Transport Cytochromes

including Cytochrome c Oxidase

Catalase

P-450s

Lipoxygenase

Cyclo-Oxygenase

Xanthine Oxidase

Peptidylprolyl and

Peptidyllysyl Oxidases

Catechol Dioxygenases

Nitric Oxide (Nitrogen Monoxide) Synthase
Function

Reduction of oxygen

Superoxide disproportionation

Synthesis of dihydroxyphenylalanine Synthesis of norepinephrine and epinephrine Synthesis of norepinephrine and epinephrine Metabolism of primary amines

Blood clotting

$\mathrm{Cu}$ transport, mobilization of stored $\mathrm{Fe}$, and angiogenesis, down-regulation of nitric oxide synthase (NOS)

Synthesis of neuroendocrine hormones including: gastrin, choleocystokinin, melanocyte stimulating hormone, calcitonin, vasopressin, secretin, and some enkephalins Collagen and elastin cross-linking

Normal metalloglycoprotein located on the extracellular surface of many cell types of unknown function

Synthesis of methione from homocysteine May have a role in decreasing amyloid $A^{\beta}$ protein synthesis and increasing secretion of amyloid precursor protein

Activates Adenylyl Cyclase and

Modulates inducible Nitric Oxide

Synthase (NOS)

$\mathrm{Cu}$ Chaperone for $\mathrm{Cu}_{2} \mathrm{Zn}_{2} \mathrm{SOD}$

Synthesis of c-AMP

Synthesis of c-GMP

Lipolysis

Metallothioneine gene transcription regulatory proteins

Oxidation-Reduction

Disproportionation of hydrogen peroxide

Activation of oxygen

Conversion of arachadonic acid to 5-HPETE and 5-HETE

Conversion of aracadonic acid to $\mathrm{PGG}_{2}$

Purine metabolism

Hydroxylation of procollagen and proelastin

Oxidative opening of catechol ring systems

Synthesis of nitrogen monoxide 
Manganese-dependent enzymes [5,26-32]

Mn-Dependent SOD

Arginase

Pyruvate Carboxylase

Pseudocatalase

Calmodulin-Dependent Protein

Phosphatase

$\alpha$-Isopropylmalate Synthetase

A Brain Adenylate Cyclase

Catechol-O-Methyltransferase

Farnesyl Pyrophosphate Synthetase

Glycosyl Synthetase

Extradiol-Cleaving Dioxygenase

A Ganglioside Galactosyl-

Saccharide Polymerases

Glycosyltransferases transferase

A Galactosylhydroxylysyl

connective Glucosyltransferase

Phosphatases

Restriction Endonucleases

Xylose Isomerase

Catalases

Extradiol-Cleaving Catechol Dioxygenases

Zinc-dependent enzymes [5,33-36]

$\mathrm{Cu}_{2} \mathrm{Zn}_{2} \mathrm{SOD}$

Aminopeptidase

Aldehyde Hydrase

Esterase

Methylmalonyl-Oxaloacetate

Transcarboxylase

Carboxypeptidases A and B

NAD-Dependent Dehydrogenases

Carbonic Anhydrase

$\alpha$-Hydroxyacid Dehydrgenase

Alkaline Phosphatase

Purine and Pyrimidine

Nucleoside Kinases

DNA Polymerase and Gyrase

"Zinc-Finger" proteins

Matrix Metalloproteinases

Metal-Responsive Transcription Factor-1
Disproportionation of superoxide

Syntheses of urea and ornithine

Synthesis of oxaloacetate

Disproportionation of $\mathrm{H}_{2} \mathrm{O}_{2}$

Phosphate ester hydrolysis

Synthesis of $\alpha$-isopropylmalate

Synthesis of c-AMP

Synthesis of catechol methyl ether

Synthesis of farnesyl pyrophosphate

Synthesis of glycosyl-phosphonucleotides

Insertion of dioxygen

Galactose transfer

Synthesis of polymeric carbohydrates

Synthesis of glycosides

Glycosaminoglycan and glycoprotein

tissue component syntheses

Phosphate ester hydrolysis

DNA recognition and cleavage

Isomerization of xylose

Disproportionation of hydrogen peroxide

Oxidative opening of catechol ring systems

Disproportionation of superoxide

Protein hydrolysis

Aldehyde hydration

Ester hydrolysis

Transcarboxylation

Protein hydrolysis

Oxidations

Dehydration of carbonic acid

Oxidation of $\alpha$-hydroxy acids

Phosphorylation

Phosphorylation of nucleosides

DNA synthesis

Transcription regulating proteins

Endopeptidases required for repair,

maintenance, and function of extracellular connective tissue components and wound repair

Metalloelement transcription factor, a

$\mathrm{Zn}$-finger regulatory protein required for cellular response in metalloelement uptake

\section{Essential Metalloelement Metabolism}

Ingested foods and beverages contain these essential metalloelements in chelated forms, which may yield other chelates as a result of ligand exchange in the digest or following absorption [4]. However, some of the absorbed chelates may exist in the digest and in blood as the original chelate or a more stable ternary chelate. Absorbed metalloelement chelates undergo systemic circulation to all tissues and utilization by all cells following ligand exchange with small molecular mass ligands, apoproteins, and apoenzymes to form metalloproteins and metalloenzymes in de novo syntheses. These metalloelements are stored in the appropriate tissues as MTs or Fe-Ferritin, or they are excreted in the event tissue needs have been met and stores 
replenished [4]. There are no inducible excessive storage diseases known in normal individuals. However, there must be upper limits dictated by physiological requirements.

Stored essential metalloelements are released as chelates via ligand exchange to meet normal metabolic needs. This homeostatic release of relatively small amounts of essential metalloelement chelates meets normal physiologic requirements. Release of larger quantities in a pronounced mobilization of these metalloelements is a feature of interleukin-1 (IL-1) and other cytokine mediated acute and chronic responses to many disease states [ 4 and cited refs].

It is likely that the magnitude of these responses is adequate in normal well-nourished individuals and allows them to overcome their disease. However, it is now generally recognized that dietary intakes of $\mathrm{Cu}, \mathrm{Fe}$, $\mathrm{Zn}[37,38]$, and most likely $\mathrm{Mn}$ are less than recommended daily intakes for the U.S. population and may be no better for individuals living in other developed countries. Individuals who have depleted stores of these essential metalloelements, such as chronic disease patients, may overcome pathology associated with their disease state, which always involves inflammation, more slowly or not at all. The degree of radiation injury and the nutritional state of health of an individual may determine whether or not an individual will be able to overcome metalloelement-dependent repairable radiation injury. Treatment with essential metalloelement chelates either before and/or after radiation injury may support these essential metalloelement-dependent responses or facilitate recovery regardless of the state of nutriture.

\section{Chemical Consequences of Ionizing Radiation}

Since water represents $70 \%$ of the chemical composition of the adult body ( $90 \%$ of the infant body), its chemical transformation by ionizing radiation merits serious consideration with regard to chemical consequences of ionizing radiation. Ionizing radiolysis of water is well understood and produces very reactive aquated electrons, monoatomic hydrogen atoms, hydroxyl radical, hydrogen peroxide, and protonated water as well as superoxide $\left(\mathrm{O}_{2}{ }^{-}\right)$and hydroperoxyl radical in the presence of oxygen. Hydroperoxyl radical, hydroxyl radical, monoatomic hydrogen, and aquated electrons have very short half-lives of the order of milliseconds and consequently react rapidly with cellular components in reduction, oxidation, initiation, insertion, propagation, and addition reactions causing loss of function and the need for biochemical replacement and/or repair. Ionizing radiation can also impart sufficient energy to all biochemicals to cause homolyltic bond breaking and produce all conceivable organic radicals in considering $\mathrm{C}-\mathrm{C}, \mathrm{C}-\mathrm{N}, \mathrm{C}-\mathrm{O}, \mathrm{C}-\mathrm{H}, \mathrm{P}-\mathrm{O}, \mathrm{S}-\mathrm{O}$, etcetera bond homolyses. These radicals will undergo the above listed radical reactions to cause further destruction and the need for replacement and/or repair. A third consequence of ionizing radiation is homolytic or heterolytic bond breaking of coordinate-covalent bonded metalloelements. These are the weakest bonds in biochemical molecules and potential sites of greatest damage, which may be most in need of replacement and/or repair since many repair enzymes are metalloelement-dependent.

Recognizing that loss of essential metalloelement-dependent enzyme activity may at least partially account for lethality of ionizing radiation and that $\mathrm{Cu}-, \mathrm{Fe}-, \mathrm{Mn}-$, and $\mathrm{Zn}$-dependent enzymes have roles in protecting against accumulation of $\mathrm{O}_{2}{ }^{-}$as well as facilitating repair [39] may explain the radiation protection and radiation recovery activities of $\mathrm{Cu}, \mathrm{Fe}, \mathrm{Mn}$, and $\mathrm{Zn}$ compounds. It is suggested that the IL-1 mediated redistributions of essential metalloelements have a general role in responding to radiation injury. These redistributions may also account for subsequent de novo synthesis of metalloelement-dependent enzymes required for biochemical repair and replacement of cellular and extracellular components needed for recovery from radiolytic damage.

De novo syntheses of metalloelement-dependent enzymes required for utilization of oxygen and prevention of $\mathrm{O}_{2}{ }^{-}$accumulation as well as tissue repair processes including metalloelement-dependent DNA and RNA repair are key to the hypothesis that essential metalloelement chelates decrease and/or facilitate recovery from radiation-induced pathology. A widely held understanding is that $\mathrm{O}_{2}{ }^{-}$accumulates in mammalian cellular and extracellular spaces due to the lack of normal concentrations of $\mathrm{Cu}$ and $\mathrm{Zn}$-or $\mathrm{Mn}$ dependent superoxide dismutases ( $\mathrm{SODs}$ ), inappropriate reduction of $\mathrm{O}_{2}$ leading to relatively large steady-state concentrations of $\mathrm{O}_{2}{ }^{-}$, or inappropriate release of $\mathrm{O}_{2}{ }^{-}$from oxygen activating centers. Increasing synthesis of $\mathrm{O}_{2}{ }^{-}$as the result of the conversion of Xanthine Dehydrogenase, which does not synthesize $\mathrm{O}_{2}{ }^{-}$, to Xanthine Oxidase which does synthesize $\mathrm{O}_{2}{ }^{-}$has been recently demonstrated in the liver of 3 to 9 Gray (Gy) irradiated mice [40]. More reactive oxygen-radicals derived from $\mathrm{O}_{2}{ }^{-}$include: singlet oxygen and hydrogen peroxide, produced as a result of acid-dependent self disproportionation or water-catalyzed disproportionation of $\mathrm{O}_{2}^{-}$. hydroxyl radical, and hydroperoxyl radical $[41,42]$. Facilitated de novo syntheses of $\mathrm{Cu}_{2} \mathrm{Zn}_{2} \mathrm{SODs}$ and catalase 
and decreasing or preventing formation of these oxygen-radicals may account for some of the recovery from pathological changes associated with irradiation, which cause systemic inflammatory disease and immunoincompetency in the case of whole-body irradiation, and focal inflammatory disease associated with local irradiation.

\section{Radiation-Induced Tissue Injury}

Ionizing radiation is known to cause a variety of tissue injuries at all levels of biochemical systems. Acutely toxic radiation syndromes are well known in terms of doses of radiation and clinical courses of these syndromes [43]. Doses of radiation that are less than those that cause death in the short term as well as ultraviolet irradiation cause a variety of disease states depending upon the biochemical injury of the affected tissues. Consequences of ionizing and ultraviolet irradiation are a matter of current concern. Radiation risk of fatal malignancy associated with commonly performed coronary angiography was found to be around 1 in 6,000 with a risk of fatal lung cancer of about 1 in 8,000 , an increase of $0.017 \%$ above the normal incidence for the general population [44]. Longer and more complicated procedures carry a greater risk consistent with the well known phenomenon of radiation-induced carcinogenesis [45]. Radiation-Induced skin injury is also an unwanted consequence of this procedure and more so for all ex vivo irradiations of neoplastic tumors [44].

Adult CF male rats x-irradiated with 0.015 centiGy sec $^{-1}$ day $^{-1}$ for 7 days followed by 7 days rest for either 3 months or 6 months showed duration related patchy skin hyalinization, which became completely hyalinized during the succeeding 6 months without irradiation [46]. The concentration of $\mathrm{Zn}$ in skin of these rats remained normal in both irradiated groups but by the end of 1 yr it had significantly $(P<0.001)$ decreased to $13 \mu \mathrm{g} \mathrm{gm}^{-1}$ of tissue from $19 \mu \mathrm{g} \mathrm{gm}^{-1}$. Skin Fe was elevated in both irradiated groups and the elevation increased from $100 \mu \mathrm{g} \mathrm{gm}^{-1}$ of tissue with 3 mo irradiation to $140 \mu \mathrm{g} \mathrm{gm}^{-1}$ after 6 mo irradiation versus $68 \mu \mathrm{g}$ $\mathrm{gm}^{-1}$ for control skin. There was a further relative increase in skin Fe $1 \mathrm{yr}$ after irradiation to $129 \mu \mathrm{g} \mathrm{gm}^{-1}$ of tissue compared to $65 \mu \mathrm{g} \mathrm{gm}^{-1}$ for control skin $(\mathrm{P}<0.001)$. It was concluded that chronic exposure to low dose $\mathrm{x}$-irradiation possibly causes a redistribution of $\mathrm{Zn}$ and $\mathrm{Fe}$ with concomitant hyalinization of collagen. The observed skin collagen pathology and altered essential metalloelement contents were interpreted as results of chronic inflammation due to chronic irradiation [46].

Recent studies of pregnant women who resided in a heavily exposed area of the Republic of Belarus following the Chernobyl catastrophe appear to be at risk for development of toxemia, renal insufficiency, and anemia. Neonates born in heavily contaminated areas were found to be at risk for development of anemia, congenital malformations, and perinatal death. Decreased concentrations of erythrocyte $\mathrm{Cu}$ and $\mathrm{Zn}$ were documented for these neonates. Diminished white blood cell, T-helper cell, and T4 cell counts were found for neonates from areas of heavy exposure [47].

\section{Radiation Protection and Recovery with Copper Chelates.}

Small non-toxic doses of $\mathrm{Cu}(\mathrm{II})_{2}(3,5-\mathrm{DIPS})_{4}$ ranging form 5 to $80 \mu \mathrm{mol} \mathrm{kg}{ }^{-1}$ of body mass increased survival of lethally irradiated mice treated orally or subcutaneously (sc) before irradiation, while smaller doses ranging down to $2.5 \mu \mathrm{mol} \mathrm{Cu(II)})_{2}(3,5-\mathrm{DIPS}){ }_{4} \mathrm{~kg}^{-1}$ given $\mathrm{sc} 3 \mathrm{hr}$ after irradiation, the radiation recovery paradigm, also increased survival [48 and cited refs.]. In a recent radiorecovery study, doses of 5,10 , or 20, $\mu \mathrm{mol} \mathrm{Cu}(\mathrm{II})_{2}(3,5-\mathrm{DIPS})_{4} \mathrm{~kg}^{-1}$ given $3 \mathrm{hr}$ after $\mathrm{LD}_{50 / 30}\left(8 \mathrm{~Gy}, 1.4 \mathrm{~Gy} \mathrm{~min}^{-1}\right)$ irradiation produced survivals of $52 \%, 60 \%$, or $52 \%$, increases of $63 \%, 88 \%(\mathrm{P}<0.05)$, or $63 \%$, respectively, compared to vehicle-treated control mice, and also facilitated recovery of radiation-induced loss of body mass $(\mathrm{P}<0.05)$ and recovery of radiation-induced loss of physical activity (locomotion) $(\mathrm{P} \leq 0.001)$ [49].

Doses of 5,10 , or $20 \mu \mathrm{mol} \mathrm{Cu}(\mathrm{II}) \mathrm{Cl}_{2}$, or 5,10 , or $20 \mu \mathrm{mol} \mathrm{Cu}(\mathrm{II})_{2}(3,5-\mathrm{DIPS})_{4} \mathrm{~kg}^{-1}$ administered sc 3 $\mathrm{hr}$ after $\mathrm{LD}_{50 / 30}$ whole-body irradiation facilitated recovery of radiation-induced systemic inflammatory disease, recovery of lost body mass, and increased survival. Treatment with 5,10 , or $20 \mu \mathrm{mol} \mathrm{Cu}(\mathrm{II}) \mathrm{Cl}_{2} \mathrm{~kg}^{-1}$ produced $7 \%, 21, \%$ or $29 \%$ increases in survival, respectively, compared to the vehicle-treated group, which is consistent with the activity reported by others [see 48]. However, treatment with 5,10 , or $20 \mu \mathrm{mol} \mathrm{Cu}(\mathrm{II})_{2}(3,5-$ DIPS $)_{4} \mathrm{~kg}^{-1}$ produced increases of $44 \%, 67 \%$, or $44 \%$ survival, respectively, compared to the vehicle-treated group. The recovery of radiation-induced loss in body mass and increased survival of mice treated with either $\mathrm{Cu}(\mathrm{II}) \mathrm{Cl}_{2}$ or $\mathrm{Cu}(\mathrm{II})_{2}(3,5 \text {-DIPS })_{4}$ document that both $\mathrm{Cu}$ compounds are effective radiorecovery agents. However $\mathrm{Cu}(\mathrm{II})_{2}(3,5-\mathrm{DIPS})_{4}$, the more bioavailable form of $\mathrm{Cu}$ is more effective than $\mathrm{Cu}(\mathrm{II}) \mathrm{Cl}_{2}[50]$.

All radiation protection and radiation recovery doses of $\mathrm{Cu}(\mathrm{II})_{2}(3,5-\mathrm{DIPS})_{4} \mathrm{Cu}(\mathrm{II})_{2}(3,5-\mathrm{DIPS})_{4}$ are non-toxic and ranged from $1 / 5$ to $1 / 100$ of an acutely toxic dose $\left(\mathrm{LD}_{50 / 7}\right)$ for male or female mice [see 48 ]. The $\mathrm{LD}_{50 / 7}$, acute toxicity, of $\mathrm{Cu}(\mathrm{II})_{2}(3,5-\mathrm{DIPS})_{4}$ in female mice and rats, $261 \pm 36 \mu \mathrm{mol} \mathrm{kg}{ }^{-1}$, was much higher than 
observed for male mice and rats, $91 \pm 13 \mu \mathrm{mol} \mathrm{kg}{ }^{-1}$. Acutely lethal doses of $\mathrm{Cu}(\mathrm{II})_{2}(3,5-\mathrm{DIPS})_{4}$ produce marked CNS depression due to loss of parasympathetic regulation of cardiac and pulmonary function. Smaller doses produce short duration hypnotic or sedative effects. The small doses of $\mathrm{Cu}$ (II)2(3,5-DIPS4 exhibiting radioprotectant and radiorecovery activity do not produce any of these CNS depressant effects. Of perhaps still greater interest with regard to many studies of supposed "Cu-mediated toxicity" as having a role in an "oxidative etiology", suggested to account for pathology of many disease states, is the recent report pointing out that these studies were seriously flawed [51]. The same increase in $532 \mathrm{~nm}$ absorbance measured following the addition of thiobarbituric acid to disease-related biological systems to which ionically bonded forms of $\mathrm{Cu}$ had been added to "catalyze oxidations", was observed following addition of ionically bonded $\mathrm{Cu}$ to aqueous solutions of only thiobarbituric acid. The linear increase in this $532 \mathrm{~nm}$ absorbance was related to the increase in $\mathrm{Cu}$-thiobarbiturate chelate(s)formation.

Initial studies involving treatment of $\mathrm{LD}_{100 / 50}$ irradiated mice after irradiation employed a dose of 80 $\mu \mathrm{mol} \mathrm{Cu}(\mathrm{II})_{2}(3,5-\mathrm{DIPS})_{4} \mathrm{~kg}^{-1}$ which was found to be effective in increasing survival when given before irradiation. However this dose given after irradiation caused acute lethality, all of these treated mice died before the vehicle-treated mice (non-published). The rationale for this observation is that treatment with this large dose of $\mathrm{Cu}(\mathrm{II})_{2}$ (3,5-DIPS $)_{4}$ after irradiation interfered with de novo synthesis of other essential metalloelement-dependent enzymes required for repair of radiation injury and decreased survival. That is, only a fraction of the dose given before radiation remains when radiation-injury occurs and this fraction is useful in overcoming radiation-injury and increasing survival. Giving this large dose of $\mathrm{Cu}(\mathrm{II})_{2}(3,5-\mathrm{DIPS})_{4}$ after irradiation may interfere with the synthesis of other metalloelement-dependent enzymes by enabling incorporation of the incorrect metalloelement, in this case $\mathrm{Cu}$, when the larger dose is given after radiation injury. This possibility also offers a rationale for historical observations that large doses of $\mathrm{Cu}, \mathrm{Fe}, \mathrm{Mn}$, and $\mathrm{Zn}$ compounds cause "radiosensitization", reducing survival and increasing radiation-induced mortality. Large doses of aminothiol radioprotectants that are effective in increasing survival of lethally irradiated mice when given before irradiation are also lethal when given after irradiation.

\section{Mechanistic Modes of $\mathrm{Cu}$ Chelate Action.}

The copper chelate of 5-diethylsulfonamoylsalicylic acid [Cu(II)(5-DESS)] has been recently reported to be effective in increasing survival of $\mathrm{LD}_{50 / 30}\left(8 \mathrm{~Gy}, 1.4\right.$ to $\left.1.3 \mathrm{~Gy} \mathrm{~min}^{-1}\right)$ irradiated mice. Treatment with 10 , $20,40,60,80,100$, or $120 \mu \mathrm{mol} \mathrm{kg}{ }^{-1}$ given sc before irradiation revealed that 80 or $120 \mu \mathrm{mol} \mathrm{kg} \mathrm{kg}^{-1}$ produced significant increases in survival, $68 \%(\mathrm{P}=0.019)$ or $92 \%(\mathrm{P}=0.0008)$, respectively, compared to vehicletreated control mice [52].

Copper(II $)_{2}$ (3,5-DIPS $)_{4}$ did not prevent hematopoietic and immunologic damage to irradiated mice, since $98-99 \%$ of myeloid progenitor cells were destroyed and immune reactivity was ablated. However, $\mathrm{Cu}(\mathrm{II})_{2}(3,5 \text {-DIPS })_{4}$ did accelerate cellular repopulation of bone marrow and spleen following irradiation. Recovery of hematopoietic activity was accelerated whether mice were treated with Cu(II) $)_{2}(3,5-\mathrm{DIPS})_{4} 3 \mathrm{hr}$ before or $3 \mathrm{hr}$ after irradiation and treatment increased levels of multipotential progenitor cells, which serve as a source of hoth myeloid and lymphoid progenitor cells, to account for recovered responses to $T$ and $B$ cell mitogens and antibody responses to a T-dependent antigen [see 48].

Radiorecovery and/or radioprotectant activity of Cu-containing compounds or complexes should be recognized as possibly facilitating activation of $\mathrm{Cu}$-dependent proteins and enzymes required for repair of radiation injury, including induction of metallothioneine (MT) synthesis, and recovery of radiation-induced immuno-incompetency. In this context, cytokines such as interleukin-1 (IL-1), tumor necrosis factor, stem cell factor, and interleukin-12 have recently been suggested to restore function to tissues damaged by irradiation and protect mice from radiation lethality when given before irradiation [53]. In contrast, cytokines such as transforming growth factor $\beta$, interleukin -6 , and interferon, given before irradiation, sensitize mice and increase radiation lethality [54]. It is most likely that there are complex cytokine interactions relevant to the amount of cytokine synthesized and timing of release in responding to the degree of radiation injury. Additional evidence for this comes from the correlation between survival of irradiated keratinocytes and the synthesis of IL-6 [55]. It is also known that changes in ceruloplasmin (Cp), a Cu-dependent multifunctional plasma enzyme, the plasma $\mathrm{Zn}$ containing $\alpha_{2}$-macroglobulin, and transferrin, the plasma $\mathrm{Fe}$ transporter, mediated responses to injury are regulated by $\mathrm{IL}-1$ and other cytokines in facilitating tissue repair processes. Addition of inflammatory cytokines; IL- $1 \alpha$, IL-1 $\beta$ or inorganic $\mathrm{Cu}$ to hepatocyte culture medium increased mRNA for MT-1, MT-2, and $\mathrm{Cp}$ in a coordinated cytokine-activation of hepatic cells as an acute phase response to inflammation [56]. These observations offer a clearer understanding of the well-known cytokine- 
mediated acute phase response to inflammation and the increase in $\mathrm{Cp}$ as an acute phase response to irradiation-induced inflammation.

Following the observed radioprotectant and radiorecovery activities of $\mathrm{Cu}(\mathrm{II})_{2}(3,5-\mathrm{DIPS})_{4}$ as well as its facilitation of recovery of radiation-induced immuno-incompetency, the question still remained as to whether or not there was any correlation between these observations and repair or recovery of radiationinduced histopathology. To address this need histopathological studies of spleen, bone marrow, thymus, and small intestine were conducted in parallel with immunological studies of animals exposed to $\mathrm{LD}_{50 / 30}$ irradiation $\left(8.0 \mathrm{~Gy}, 1.55 \mathrm{~Gy} \mathrm{~min}^{-1}\right)$ alone, treatment with $40 \mu \mathrm{mol} \mathrm{kg}{ }^{-1} \mathrm{Cu}(\mathrm{II})_{2}(3,5-\mathrm{DIPS})_{4}$ alone, or irradiated and treated with a single dose of vehicle or $\mathrm{Cu}(\mathrm{II})_{2}(3,5-\mathrm{DIPS})_{4}$. Treatment with $\mathrm{Cu}(\mathrm{II})_{2}(3,5-\mathrm{DIPS})_{4}$ brought about repair of radiation-induced histopathology in these tissues [see 48]. Signs of recovery were demonstrable by the 7th to 14 th day after irradiation. These observations lead to the general conclusion that although $\mathrm{Cu}(\mathrm{II})_{2}(3,5-\mathrm{DIPS})_{4}$ does not prevent tissue injury when it is given before irradiation. Treatment with this chelate facilitates rapid tissue recovery from radiation-induced injuries. These recoveries from radiation-induced histopathology offer a biological marker for the re-establishment of the integrity of tissues known to be most vulnerable to irradiation.

The earlier review [see 48] also pointed out that $\mathrm{Cu}(\mathrm{II})_{2}(3,5-\mathrm{DIPS})_{4}$ inhibits radiation-induced carcinogenesis and clastogenesis consistent with suppression of DNA replication and blockade of cell growth in the $\mathrm{S}$ phase as well as repair of DNA strand breaks. These effects are also consistent with reported anticlastogenic activity of $\mathrm{Cu}$ (II)(glycinate) ${ }_{2}$, observed as a rapid recovery of bone marrow cell radiation injury and associated repair of DNA [see 48]. They are also consistent with the prevention or repair of DNA strand breaks by $\mathrm{Cu}(\mathrm{II})_{2}$ (indomethacinate) ${ }_{4}$ in phorbol-treated human leukocytes and support $\mathrm{Cu}$-dependent mechanisms for prevention or repair of radiation-induced DNA damage.

Whole body and local irradiation injury constitutes either systemic or local inflammation. Consistent with the antiinflammatory activities of $\mathrm{Cu}$ chelates [57], $\mathrm{Cu}(\mathrm{II})_{2}(3,5-\mathrm{DIPS})_{4}$ has been found to be effective in facilitating repair of systemic inflammation caused by whole body irradiation (vide supra) and local inflammatory reactions. Ear swelling of female $\mathrm{C} 3 \mathrm{H}$ mice treated $2 \mathrm{hr}$ before porphyrin photosensitization and visible (480 to $645 \mathrm{~nm}$ ) irradiation with 20,40 , or $80 \mu \mathrm{mol} \mathrm{kg}{ }^{-1} \mathrm{Cu}$ (II) $)_{2}(3,5-\mathrm{DIPS})_{4}$ produced dose-related decreases in porphyrin-mediated photosensitized ear swelling of $25 \%, 50 \%$, or $90 \%$,respectively, with a dramatic decrease in photosensitization-induced histopathology, suggested to be $\mathrm{O}_{2}^{-}$-mediated inflammation due to activation of Xanthine Oxidase (XO) [58]. This inflammation was inhibited by Allopurinol, an inhibitor of $\mathrm{XO}$, and Verapamil, a Ca-channel blocker (vide infra) suggested to prevent the isoenzyme transformation of Xanthine Dehydrogenase (XD) to XO [59], the form of this enzyme that synthesizes $\mathrm{H}_{2} \mathrm{O}_{2}$ and $\mathrm{O}_{2}^{-}$. Consistent with this suggestion, ultraviolet epidermal cell injury of mouse ears (ultraviolet erythema, a recognized model of inflammation) was decreased with $\mathrm{Cu}_{2} \mathrm{Zn}_{2} \mathrm{SOD}$ treatment and inhibition of $\mathrm{Cu}_{2} \mathrm{Zn}_{2} \mathrm{SOD}$ by treatment with diethyldithiocarbamate exacerbated the "sunburn cell" formation but did not change ultraviolet radiationinduced ear swelling [60]. Ultraviolet irradiated human endothelial cells elaborate nitrogen monoxide (NO) which may account for vasodilation and ear swelling as an inflammatory response [61] following activation of inducible Nitrogen Monoxide Synthase (NOS).

The observed decrease in skin $\mathrm{Cu}_{2} \mathrm{Zn}_{2} \mathrm{SOD}$ following a single ultraviolet irradiation was also reduced by pretreatment with liposomes containing $\mathrm{Cu}_{2} \mathrm{Zn}_{2} \mathrm{SOD}$ [62]. Increased ultraviolet radiation-induced keratinocyte proliferation was also found to be associated with a decrease in total SOD activity which was due mainly to a decrease in $\mathrm{Cu}_{2} \mathrm{Zn}_{2} \mathrm{SOD}$ [63]. Protection against ultraviolet radiation-induced chronic skin damage was also found with topically applied non-steroidal antiinflammatory agents [64]. These agents have been suggested to form $\mathrm{Cu}$ chelates in vivo [57], which may account for their inhibition or repair of ultraviolet radiation induced injury.

Copper(II $)_{2}$ (3,5-DIPS $)_{4}$ was originally examined for radioprotectant activity based upon reports that $\mathrm{Cu}_{2} \mathrm{Zn}_{2} \mathrm{SOD}$ had radioprotectant activity when given both before and after irradiation. However, subsequent reports suggested that superoxide disproportionation by $\mathrm{Cu}_{2} \mathrm{Zn}_{2} \mathrm{SOD}$ did not account for its radioprotectant activity. Inactivated polyethylene-glycol derivatized $\mathrm{Cu}_{2} \mathrm{Zn}_{2} \mathrm{SOD}$ was as effective as the enzymatically active derivative. The very real possibility that these proteins in extracellular spaces are in fact antigenic, although reduced antigenicity is always claimed, may lead to phagocyte elaborated IL-1 and/or some other cytokine(s) that initiates immune and repair responses that accounted for the observed increase in survival [see 48].

The hypothesis that there are radiolytic losses of essential metalloelement-dependent enzyme cofactors [see 48] has merit and is consistent with the report that there was a $20 \%$ loss of both $\mathrm{Cu}_{2} \mathrm{Zn}_{2} \mathrm{SOD}$ and $\mathrm{MnSOD}$ in intestinal smooth muscle of rats immediately (1 hr) following irradiation (15 Gy). However, the 
activity of both enzymes increased over a $20 \mathrm{hr}$ post-irradiation period to a level $45 \%$ higher than normal with a further increase in Mn SOD by $72 \mathrm{hrs}$ post irradiation, a likely result of de novo synthesis in response to injury. It is noteworthy that $\mathrm{Cu}(\mathrm{II})_{2}(3,5 \text {-DIPS })_{4}$, a SOD-mimetic, was subsequently found to be more effective as a radioprotectant and radiorecovery agent than $\mathrm{Cu}_{2} \mathrm{Zn}_{2} \mathrm{SOD}$ and more effective than WR-2721 in reducing oxygen radical mediated colitis [65].

Adult $\mathrm{CF}$ male rats $\mathrm{x}$-irradiated with $15 \mathrm{cGy} \mathrm{sec}^{-1}$ day $^{-1}$ for 7 days followed by 7 days rest for either 3 months or 6 months showed duration related radiation-induced patchy skin hyalinization, which became completely hyalinized during the succeeding 6 months without irradiation [66]. The concentration of $\mathrm{Zn}$ in skin of these rats remained normal in both irradiated groups but by the end of $1 \mathrm{yr}$ it had significantly $(\mathrm{P}<$ 0.001 ) decreased to $13 \mu \mathrm{g} \mathrm{gm}^{-1}$ of tissue from $19 \mu \mathrm{g} \mathrm{gm}^{-1}$. Skin Fe was elevated in both irradiated groups and the elevation increased from $100 \mu \mathrm{g} \mathrm{gm}^{-1}$ of tissue with 3-mo irradiation to $140 \mu \mathrm{g} \mathrm{gm}^{-1}$ after 6-mo irradiation versus $68 \mu \mathrm{g} \mathrm{gm}^{-1}$ for control skin. There was a further relative increase in skin Fe $1 \mathrm{yr}$ after irradiation to 129 $\mu \mathrm{g} \mathrm{gm}{ }^{-1}$ of tissue compared to $65 \mathrm{\mu g} \mathrm{gm}^{-1}$ for control skin $(\mathrm{P}<0.001)$. It was concluded that chronic exposure to low dose irradiation possibly causes a redistribution of $\mathrm{Zn}$ and $\mathrm{Fe}$ with concomitant hyalinization of collagen. The observed skin collagen pathology and altered essential metalloelement contents were interpreted as results of chronic inflammation due to chronic irradiation [66]. These changes in skin essential metalloelement contents are consistent with essential metalloelement-dependent enzyme responses required to overcome radiation injury.

Reduction in radiation-induced fibrosis with liposomal $\mathrm{Cu}_{2} \mathrm{Zn}_{2} \mathrm{SOD}$ was studied using large white pigs $\gamma$-irradiated with a single dose of $160 \mathrm{~Gy}$ delivered to the skin. Treatment with $0.3 \mu$ mol $\mathrm{Cu}_{2} \mathrm{Zn}_{2} \mathrm{SOD}$ applied 2 times per week for $3 \mathrm{wk}$ caused shrinking of irradiation-induced fibrosis in all treated pigs. Scar regression was found to be $45 \%$ in length and width, $30 \%$ in depth, and $70 \%$ in area and volume. Histologic examination showed normal muscle and subcutaneous tissue surrounding the residual scar. This replacement of scar tissue by normal tissues and a $50 \%$ decrease in the linear dimensions of the scar were comparable to results obtained in a previous clinical trial of liposomal $\mathrm{Cu}_{2} \mathrm{Zn}_{2} \mathrm{SOD}$ treatment [67].

Over expression of $\mathrm{Cu}_{2} \mathrm{Zn}_{2} \mathrm{SOD}$ or MnSOD increased survival of 0.2 to $1.2 \mathrm{~Gy}\left(0.3 \mathrm{~Gy} \mathrm{~min}^{-1}\right) \mathrm{x}$ irradiated $\mathrm{CHO}$ cells and cells over-expressing MnSOD had greater survivals that those over-expressing $\mathrm{Cu}_{2} \mathrm{Zn}_{2} \mathrm{SOD}$ [68]. As pointed out earlier [see 48] the SOD-mimetic reactivity of $\mathrm{Cu}(\mathrm{II})_{2}$ (indomethacinate) was credited with the prevention of DNA strand-breaks in human leukocytes stimulated with phorbol-diester. This prevention or facilitated repair of DNA was observed over a concentration range of 2 to $9 \mu \mathrm{M}$ $\mathrm{Cu}(\mathrm{II})_{2}$ (indomethacinate $)_{4}$.

Another possible mechanism offered to account for the radioprotectant and radiorecovery activities of $\mathrm{Cu}$ chelates involves $\mathrm{Cu}$-dependent nuclear metabolism. It is known that $20 \%$ of cellular $\mathrm{Cu}$ is found in the nucleus. Copper has the highest bonding affinity for nucleic acids of all essential metalloelements. Nucleic acid phosphate and base donor sites yield $\mathrm{Cu}$ chelates, which are much more stable than $\mathrm{Cu}$ chelates of most amino acids and near the stability of protein chelates. This stability has been used to support suggestions of intrastrand and interstrand DNA bridging, which was recognized early as having a role in stabilization of the Watson-Crick double helix [see 48]. Higher physiologic concentrations account for inhibition of ribonuclease syntheses: initiation, nucleotide condensations, and release of newly formed mRNA. However, the original observation that injection of $\mathrm{Cu}(\mathrm{II}) \mathrm{Cl}_{2}$ into rats induced the synthesis of mRNA coding for the synthesis of MT has been explained as due to the formation of a $\mathrm{Cu}$-dependent DNA bonding protein ACE1 or CUP2, the protein products of $S$. cerevisiae (ACE1) and $E$. coli (CUP2) genes, which recognize upstream activation sequences required for active transcription of CUPI, a MT gene as pointed out earlier [see 48] and subsequently [69]. Chaperones such as hAtoxl are $\mathrm{Cu}$ bonding proteins suggested to have roles in mediating $\mathrm{Cu}$ homeostasis in many cell types as cytosolic $\mathrm{Cu}$-transporters, enabling the utilization of $\mathrm{Cu}$ in de novo synthesis of $\mathrm{Cu}$-dependent enzymes and proteins [70]. Since radiation injury and injection of $\mathrm{Cu}$ chelates induce MT synthesis and increased MT synthesis correlates with increased survival, $\mathrm{Cu}$ chaperones such as Atoxl, which mediate the role of $\mathrm{Cu}$ in transcription of $\mathrm{Cu}_{2} \mathrm{Zn}_{2} \mathrm{SOD}$ and the anti-apoptotic bcl-2 genes [71], may represent important nuclear chemical responses in overcoming radiation injury.

Nuclease-Mimetic reactivity of $\mathrm{Cu}$ chelates has been recognized as valuable footprinting reagents useful in revealing details of RNA polymerase bonding to a lac promoter [see 48]. Predictable chromatin DNA cleavage by a chelate due to preferential bonding of the chelate to DNA spacer segments is also a useful characterizing feature. Interpretations that these and other DNA strand scissions resulting from $\mathrm{Cu}$ chelates are damaging [72,73] without recognizing that these scissions may be due to expected $\mathrm{Cu}$ chelate [74] or other essential metalloelement chelate [75] catalyzed diphosphate ester hydrolyses, which may be viewed as 
endonuclease- (or exonuclease-) mimetic reactivity, merit reconsideration. More recently, the antineoplastic action of the copper complex of Tambjamine was suggested to be due to DNA nuclease reactivity [76].

Like many $\mathrm{Cu}$ chelates, $\mathrm{Cu}(\mathrm{II})_{2}(3,5 \text {-DIPS })_{4}$ has SOD-mimetic reactivity. While formation of ternary protein-Cu(II) $)_{2}(3,5 \text {-DIPS })_{4}$ chelates formed with collagen or albumin have slightly less SOD-mimetic reactivity due to protein bonding to a free $\mathrm{Cu}$ bonding site [77], it is the formation of, as yet not unequivocally demonstrated, ternary albumin chelates formed in vivo $[78,79]$ that were suggested to account for the observed rapid and pervasive tissue distribution of ${ }^{67} \mathrm{Cu}$ and ${ }^{14} \mathrm{C}$ labeled 3,5-DIPS within $0.5 \mathrm{hr}$ following administration of ${ }^{67} \mathrm{Cu}(\mathrm{II})_{2}\left[3,5-\mathrm{DIP}\left(\text { Carboxy }-{ }^{14} \mathrm{C}\right) \mathrm{S}\right]_{4}[80]$.

Dietary supplementation with arginine, the substrate for NOS, required for the synthesis of NO has been found to accelerate intestinal mucosal regeneration and enhance bacterial clearance following radiationinduced rat enteritis [81]. Rats fed diet containing $4 \%$ arginine for 7 days following non-lethal local abdominal $\mathrm{x}$-irradiation $\left(11 \mathrm{~Gy}, 0.14 \mathrm{~Gy} \mathrm{~min}^{-1}\right)$ had significantly $(\mathrm{P}<0.001)$ increased mesenteric lymph node mass, decreased number of lymph node Gram-negative enteric bacilli and facultative anaerobic bacteria, CFU gm ${ }^{-1}$ of lymph node, increased mucosal thickness, and jejunal and ileal villi height and number, as well as number of mucous cell villi compared to rats fed a diet containing $2 \%$ arginine or $4 \%$ glycine.

Copper(II $)_{2}(3,5-\mathrm{DIPS})_{4}$ has been suggested to facilitate NO mediated responses to inflammatory diseases $[82,83]$. However, it has also been found to decrease synthesis of NO by down-regulating nitric oxide synthase (NOS) enzyme activity which may account for the antiinflammatory activities of this and other $\mathrm{Cu}$ chelates as well as repair of radiation injury $[82,83]$. This is an especially interesting possibility since $\mathrm{Cp}$, which increases in plasma following irradiation, has recently been reported to decrease NOS activity when incubated with endothelial cells. There was a time-dependent increase in cytosolic and particulate bonded copper, and this effect could be reproduced by incubation with $\mathrm{Cu}(\mathrm{II})$ (histidinate $)_{2}$ but not with $\mathrm{Cu}(\mathrm{II}) \mathrm{Cl}_{2}$. which primarily bonded to all particulate fractions and less so to cytosolic components [84]. In addition, $\mathrm{Cu}_{2} \mathrm{Zn}_{2} \mathrm{SOD}$ has recently been shown to release NO from S-nitrosothiols in the presence of glutathione [85] suggesting that $\mathrm{Cu}_{2} \mathrm{Zn}_{2} \mathrm{SOD}$ might have a role in mediating constitutive or inducible NOS and facilitating NOmediated physiological functions as well as mediating rat mucosal regeneration and bacterial clearance in radiation enteritis [81].

Recently a domain of $\mathrm{Cp}$, distinct from the ferro-oxidase domain, has been reported to act as a glutathione-dependent peroxidase [86] and a glutathione-dependent alkyl hydroperoxidase [87], which offers an interesting accounting for a plasma $\mathrm{Cu}$-dependent agent responsible for removal of lipid hydroperoxides. Ceruloplasmin has also been recently identified as a plasma Pituitary Adenylate Cyclase-Activating Polypeptide (PAC-AP) 1-38-bonding factor [88]. This factor is an alpha amidated peptide, one of many amide terminus neuronal hormone peptides synthesized by $\mathrm{Cu}$-dependent $\alpha$-amidating mixed function oxidases [89]. PAC-AP has more recently been reported to prevent cytokine-induced pancreatic $\beta$-cell cytotoxicity by inhibiting inducible NOS expression in BTC cells [90]. The PACAP activity of $\mathrm{Cp}$ has also heen reported to decrease cytokine-induced cytotoxicity by inhibiting inducible NOS in pancreatic $\beta$ cells [91]. These observations offer an accounting for the radioprotectant and radiorecovery activities of $\mathrm{Cu}(\mathrm{II})_{2}(3,5$-DIPS) 4 . since $\mathrm{Cu}(\mathrm{II})_{2}(3,5 \text {-DIPS })_{4}$ has been reported to down-regulate, but not inhibit enzyme activity, NOS and decrease the synthesis of NO [81,82]. Alternatively, this $\mathrm{Cu}$ chelate as well as others may form ternary nitrogen monoxide chelates $\left(\mathrm{ON}-\mathrm{CuL}_{2}\right)$ that have a role facilitating NO dependent processes $[81,82]$.

The possibility remains that reported therapeutic actions of $\mathrm{Cu}$ chelates may be due to onlv a small portion of the administered dose bonded to serum albumin and transported to the site of action. That is, an effective antiinflammatory dose of $\mathrm{Cu}(\mathrm{II})_{2}(3,5-\mathrm{DIPS})_{4}$ is $1 \mu \mathrm{mol}$ per kilogram of body mass. This represents $10^{19}$ molecules per $70 \mathrm{~kg}$ adult treated with a supposed dose of $70 \mu \mathrm{mol}$. If only $0.01 \%$ of this dose was distributed throughout the body due to losses including excretion, each of the estimated $10^{12}$ cells in the adult body could experience contact with more than 1,000 molecules of this chelate. Since there is always an inflammatory-response mediated vasodilation at the site of disease-affected cells and greater perfusion of these affected cells by plasma filtrate, the concentration of drug in the environment of disease-affected cells could actually be greater than 1,000 molecules per cell. Smaller daily doses ranging down to $0.7 \mu$ mol per adult, which could be a more likely dose, would provide 10 molecules per cell with the loss of $99.99 \%$ of the administered dose. Such losses may be typical for all administered drugs.

\section{Radiation Protection and Recovery with Iron Chelates.}

Since radiolytic loss of $\mathrm{Fe}$ from $\mathrm{Fe}$-dependent enzymes is also a possible consequence of ionizing radiation, non-toxic doses of $\mathrm{Fe}(\mathrm{III})-(3,5 \text {-DIPS })_{3}$ were examined for radioprotectant activity. Doses ranging from 35 to $280 \mu \mathrm{mol} \mathrm{kg}^{-1}$ given sc before irradiation produced increases of $50 \%$ to $84 \%$ survival of $L_{5(0,30}$ 
irradiated ( $\left.8 \mathrm{~Gy}, 1.55 \mathrm{~Gy} \mathrm{~min}^{-1}\right)$ male mice compared to vehicle-treated mice [see 48]. Treatment sc with 35 $\mu \mathrm{mol} F$ e(III)-(3,5-DIPS) ${ }_{3} \mathrm{~kg}^{-1}$ before $\mathrm{LD}_{100 / 30}$ irradiation increased survival $300 \%$ compared to vehicle-treated mice (8\% survival). Treatment with sc doses of $17.5,35$, or $70 \mu \mathrm{mol} F e(I I I)-(3,5-\mathrm{DIPS})_{3} \mathrm{~kg}^{-1}$ after $\mathrm{LD}_{100 / 30}$ irradiation failed to increase survival above the $8 \%$ observed for vehicle-treated control mice [91]. Radiorecovery of mice treated with this chelate and irradiated with smaller doses of irradiation remain to be determined.

Gamma irradiated (7 Gy, $2.9 \mathrm{~Gy} \mathrm{~min}^{-1}$ ) young adult male DBA/2 mice treated with $16 \mu \mathrm{mol} \mathrm{kg}^{-1}$ ip Fe(III) hematoporphyrin chloride (FeHp) either 1 and 4 days or 1,4 , and 7 days after irradiation had significantly $(P<0.025)$ increased spleen colony forming units (CFU-GM) by day 14 following irradiation [92]. Mice treated on days 1 and 4 after irradiation had significantly $(P<0.025)$ increased numbers of spleen cells by day 17 post-irradiation. IronHp treatment on days 1,4 , and 7 also caused a significant $(P<0.005)$ reduction in bone marrow cell number by day 14 and other post-irradiation periods of measurement. There was no increase in bone marrow CFU-GM observed for any treatment. Mice treated $24 \mathrm{hr}$ before irradiation and $48 \mathrm{hr}$ or 48 and $96 \mathrm{hr}$ after irradiation produced significant $(\mathrm{P}<0.001)$ increases in total spleen cell number and spleen CFU-GM by day 15 post-irradiation. The single treatment after irradiation caused a 5 -fold larger increase in spleen CFU-GM number than non-irradiated or irradiated control values measured on day 15. The only significant $(\mathrm{P}<0.01)$ change in bone marrow cellularity was a decrease in cell number for mice treated $4 \mathrm{hrs}$ before and 48 and $96 \mathrm{hrs}$ after irradiation. There were no significant changes in bone marrow CFU-GM number at any time of measurement on 11,14 , and 17 days post-irradiation, relative to irradiated control mice. These data were interpreted as due to hematostimulatory activity of FeHp with stimulation occurring following radiation-induced immunosuppression. Enhanced hematopoietic recovery was observed for spleen but not bone marrow of irradiated mice treated with FeHp. Treatment may have also increased the mobilization of progenitor cells from bone marrow to the spleen in addition to the FeHp stimulatory effects on spleen CFU-GM. Interestingly, the FeHp-mediated spleen hematopoietic response was greatest in mice treated $24 \mathrm{hrs}$ before irradiation. There was no "protection" but resting hematopoietic stem cells may have been induced to begin the cell growth cycle and division, while actively dividing cells would have been at greater risk to radiation injury and cell death.

\section{Radiation Protection and Recovery with Manganese Chelates.}

The earlier review [see 48] cited a number of reports that inorganic $\mathrm{Mn}(\mathrm{II}) \mathrm{Cl}_{2}$ given sc in the radioprotectant paradigm before irradiation increased survival and enhanced survival when co-administered with aminothiol radioprotectants. Following these reports $\mathrm{Mn}(\mathrm{II}) \mathrm{Cl}_{2}$ was shown to repair radiation-induced skin and intestinal inflammation in mice [93]. Treatment with $180 \mu \mathrm{mol} \mathrm{Mn}(\mathrm{II}) \mathrm{Cl}_{2} \mathrm{~kg}^{-1}$ given ip to male C3H mice $24 \mathrm{hr}$ before a single 20 to $52 \mathrm{~Gy}\left(5 \mathrm{~Gy} \mathrm{~min}^{-1}\right)$ local paw x-irradiation or 12 to $21 \mathrm{~Gy}$ abdominal irradiation fed to repair of acute intestinal and skin radiation-injury. Skin and intestinal MT was not increased by administration of $\mathrm{MnCl}_{2}$ although a six-fold increase was found in liver. These authors failed to point out that the increase in liver MT was associated with the increase in survival of mice treated with $\mathrm{Mn}(\mathrm{II}) \mathrm{Cl}_{2}$.

Based upon the radioprotectant and radiorecovery activities observed for non-toxic doses of $\mathrm{Mn}-(3,5-$ DIPS $)_{2}$, which may either be a spherically symmetric trinuclear chelate, $\mathrm{Mn}(\mathrm{III})_{2} \mathrm{Mn}(\mathrm{II}) \mu_{3} \mathrm{O}(3,5-\mathrm{DIPS})_{6}$, or a linear trinuclear chelate, $\mathrm{Mn}(\mathrm{II})_{3}(3,5-\mathrm{DIPS})_{6}$, was examined for radioprotectant and subsequently for radiorecovery activity [see 48]. Subcutaneous treatment with 90,120 , or $150 \mu \mathrm{mol} \mathrm{Mn}-(3,5-\mathrm{DIPS})_{2} \mathrm{~kg}^{-1} 3 \mathrm{hr}$ after a $\mathrm{LD}_{70 / 30}$ irradiation again demonstrated that all three doses were effective, producing $200 \%, 229 \%$ or $214 \%$ increases in survival above vehicle-treated mice (28\% survival) [93].

Treatment with $150 \mu \mathrm{mol} \mathrm{Mn}-(3,5-\mathrm{DIPS})_{2} \mathrm{~kg}^{-1}$ before $\mathrm{LD}_{100 / 30}$ irradiation and then 30,60 , or 120 $\mu \mathrm{mol} \mathrm{kg}{ }^{-1}$ on three successive days after irradiation produced survivals of $28 \%, 12 \%$, or $16 \%$ respectively versus $0 \%$ survival for vehicle-treated mice [94]. Treatment with 90,120 , or $150 \mu \mathrm{mol} \mathrm{kg}{ }^{-1} 3 \mathrm{hrs}$ after $\mathrm{LD}_{70 / 30}$ irradiation increased survival from $7 \%$ for the vehicle-treated mice to $21 \%, 23 \%$, or $22 \%$, respectively, $200 \%$ $(\mathrm{P}=0.00007), 229 \%(\mathrm{P}=0.000005)$, or $214 \%(\mathrm{P}=0.00002)$ increases in survival compared to vehicle-treated mice [94]. Treatment with $150 \mu \mathrm{mol} \mathrm{kg}-13 \mathrm{hr}$ before $\mathrm{LD}_{100 / 30}$ irradiation $\left(10 \mathrm{~Gy}, 1.4 \mathrm{~Gy} \mathrm{~min}^{-1}\right)$ and 90,180 , or $360 \mu \mathrm{mol} \mathrm{kg^{-1 }}$ on day 2,4 , and 6 after irradiation produced $28 \%(\mathrm{P}=0.007), 12 \%$, or $16 \%$ survival, respectively, versus $0 \%$ survival for vehicle-treated mice. Treatment with 120,240 , or $480 \mu \mathrm{mol} \mathrm{Mn}-(3,5-$ DIPS) $)_{2} \mathrm{~kg}^{-1}$ before $\mathrm{LD}_{100 / 30}$ irradiation revealed that only the 240 and $480 \mu \mathrm{mol} \mathrm{kg}$ doses were effective, producing survivals of $16 \%$ or $27 \%$, respectively, with no surviving control mice [94]. Treatment with doses of 60,120 , or $240 \mu \mathrm{mol} \mathrm{Mn-(3,5-DIPS})_{2} \mathrm{~kg}^{-1}$ after $\mathrm{LD}_{100 / 30}$ irradiation revealed that only the $120 \mu \mathrm{mol} \mathrm{kg}^{-1}$ dose was effective, increasing survival $233 \%$ above control mice (12\% survival) [94]. 
Oral treatment with $\mathrm{Mn}$-(3,5-DIPS $)_{2}$ before or after $\mathrm{LD}_{100 / 30}$ irradiation increased survival and recovery of radiation-induced loss of body mass [94]. Treatment with 120,240 , or $480 \mu \mathrm{mol} \mathrm{Mn-(3,5-DIPS})_{2}$ $\mathrm{kg}^{-1}$ orally $3 \mathrm{hr}$ before irradiation or 60,120 , or $240 \mu \mathrm{mol} \mathrm{kg}^{-1} 3 \mathrm{hr}$ after irradiation increased survival and allowed greater recovery of radiation-induced loss of body mass compared to vehicle-treated mice. Treatment with 120,240 , or $480 \mu \mathrm{mol} \mathrm{Mn-(3,5-DIPS})_{2} \mathrm{~kg}^{-1}$ orally $3 \mathrm{hr}$ before irradiation produced $4 \%, 16 \%$, or $27 \%$ survival versus $0 \%$ for vehicle-treated mice. Treatment with 20,120 , or $240 \mu \mathrm{mol} \mathrm{Mn}-(3,5-\mathrm{DIPS})_{2} \mathrm{~kg}^{-1} 3 \mathrm{hr}$ after irradiation produced $12 \%, 40 \%$, or $4 \%$ survival versus $12 \%$ survival for vehicle-treated mice.

\section{Mechanistic Modes of Mn Chelate Action.}

A possible Mn-(3,5-DIPS $)_{2}$ mechanism of action in overcoming inflammation due to radiation injury is the down-regulation of NOS when excess NO is produced as part of the inflammatory response [82]. Alternatively, activation of Mn-dependent guanylyl cyclase [95], the receptor for NO, by Mn-(3,5-DIPS) $)_{2}$ may serve to restore normal physiologic functions involving NO-mediated processes. This understanding is consistent with the suggestion that a ternary NO-Mn-(3,5-DIPS $)_{2}$ complex might form in vivo [82] and have roles in mediating NO function [83].

The Mn-Desferrioxamine (MnDFO) SOD-mimetic chelate has also been found to be effective in protecting against riboflavin-mediated ultraviolet $\left(365 \mathrm{~nm}, 2\right.$ to $\left.9 \mathrm{~J} \mathrm{~cm}^{-2}\right)$ phototoxicity [96]. Photohemolysis of erythrocytes was decreased with $500 \mu \mathrm{M}$ MnDFO. Treatment with 50 or $100 \mu \mathrm{M} \mathrm{MnDFO}$ did not change ${ }^{3} \mathrm{H}$-Thymidine incorporation in irradiated $\left(5 \mathrm{~J} \mathrm{~cm}^{-2}\right)$ GH-U1 human urinary bladder carcinoma cells or irradiated $\left(10 \mathrm{~J} \mathrm{~cm}^{-2}\right)$ phytohemaglutin-stimulated lymphocytes compared to radiation alone. Higher concentrations of MnDFO were toxic to these cells.

Hahn et al. [97] and Darr et al. [98,99] suggested that MnDFO is superior to $\mathrm{Cu}$ chelates as an SODmimetic because $\mathrm{Cu}$ chelates dissociate in the presence of protein. This suggestion was offered even though $\mathrm{Cu}$ chelates are much more effective in disproportionating $\mathrm{O}_{2}{ }^{-}$at an appropriate physiological $\mathrm{pH}$ and more effectively treat many disease states (see 2). They overlook the fact that $\mathrm{Mn}$ chelates also dissociate in the presence of protein or other biochemically important macromolecules via ligand exchange. However, these losses may not prevent their use in treating diseases (vide supra et infra). More importantly they overlook the possibility that the presence of protein such as albumin can lead to ternary $\mathrm{Cu}$ or $\mathrm{Mn}$ chelate formation with enhanced stability and serve as $\mathrm{Cu}$ or $\mathrm{Mn}$ chelate transporting agents in vivo [77-79]. Consequently, the view that $\mathrm{Cu}$ or $\mathrm{Mn}$ chelates can not be effective SOD-mimetics in preventing $\mathrm{O}_{2}^{-}$-mediated pathology, despite many observations to the contrary is seriously flawed. Finally, $\mathrm{Mn}$ chelates will not serve to facilitate the activation of $\mathrm{Cu}$-dependent enzymes nor will $\mathrm{Cu}$ chelates facilitate activation of $\mathrm{Mn}$-dependent enzymes.

The SOD-mimetic reactivity of Mn(III)tetrakis-1-methyl-4-pyridylporphyrin pentachloride [Mn(III)TMPyP] was recently suggested to account for the restoration of NO-mediated neurotransmission and serves as a lead compound in the development of SOD-mimetics as therapeutic agents for the treatment of neuropathies associated with oxidant stress [100].

To examine the possibility that treatment with a combination of essential metalloelement chelates might be effective in increasing survival of lethally irradiated mice, $\mathrm{Cu}(\mathrm{II})_{2}(3,5-\mathrm{DIPS})_{4}$ and Mn-(3,5-DIPS $)_{2}$ were studied using a factorial design [101]. Treatment with 10,20 , or $40 \mu \mathrm{mol} \mathrm{Cu}(\mathrm{II})_{2}(3,5-\mathrm{DIPS})_{4} \mathrm{~kg}^{-1} \mathrm{before}$ $\mathrm{LD}_{90 / 30}$ irradiation ( $9 \mathrm{~Gy}, 1.25 \mathrm{~Gy} \mathrm{~min}^{-1}$ ) produced survivals of $28 \%, 28 \%$, or $36 \%$ survival, respectively, $133 \%, 133 \%$, or $200 \%$ increases above vehicle-treated mice (12\% survival). Increasing the dose of $\mathrm{Cu}(\mathrm{II})_{2}(3,5 \text {-DIPS })_{4}$ increased survival in these more rigorously radiation-injury-challenged mice. Treatment with 10,20 , or $40 \mu \mathrm{mol} \mathrm{Mn}-(3,5-\mathrm{DIPS})_{2} \mathrm{~kg}^{-1}$ before $\mathrm{LD}_{90 / 30}$ irradiation $\left(9 \mathrm{~Gy}, 1.25 \mathrm{~Gy} \mathrm{~min}^{-1}\right)$ produced survivals of $36 \%, 20 \%$, or $24 \%$ survival respectively, $200 \%, 67 \%$, or $100 \%$ increases in survival respectively, compared to the same vehicle-treated mice. Increasing the dose of Mn-(3,5-DIPS $)_{2}$ did not produce a doserelated increase in survival. Using combinations of 10,20 , or $40 \mu \mathrm{mol} \mathrm{Cu}(\mathrm{II})_{2}(3,5-\mathrm{DIPS})_{4}$ and 10,20 , or 40 $\mu \mathrm{mol} \mathrm{Mn}-(3,5-\mathrm{DIPS})_{2} \mathrm{~kg}^{-1}$ revealed that the combination of $20 \mu \mathrm{mol} \mathrm{Cu}(\mathrm{II})_{2}(3,5-\mathrm{DIPS})_{4}$ plus $20 \mu \mathrm{mol} \mathrm{Mn-}$ $(3,5-\mathrm{DIPS})_{2} \mathrm{~kg}^{-1}$ produced $48 \%$ survival, a $300 \%(\mathrm{P}=0.01)$ increase above the same vehicle-treated mice. While increasing the dose of $\mathrm{Cu}(\mathrm{II})_{2}(3,5-\mathrm{DIPS})_{4}$ from 10 to $40 \mu \mathrm{mol} \mathrm{kg}{ }^{-1}$ increased survival, increasing the dose of Mn-(3,5-DIPS) $)_{2}$ from 10 to $40 \mu \mathrm{mol} \mathrm{kg} \mathrm{g}^{-1}$ did not increase survival and increasing doses of $\mathrm{Mn}$-(3,5DIPS $)_{2}$ beyond $20 \mu \mathrm{mol} \mathrm{kg}{ }^{-1}$ given in combination with $\mathrm{Cu}(\mathrm{II})_{2}(3,5-\mathrm{DIPS})_{4}$ were associated with decreases in survival or no increase in survival due to combination-treatment. This apparent negative effect on survival associated with increasing doses of Mn-(3,5-DIPS $)_{2}$ given in combination with $\mathrm{Cu}(\mathrm{II})_{2}(3,5-\mathrm{DIPS})_{4}$ may be due to an interference of $\mathrm{Mn}$ in de novo synthesis of $\mathrm{Cu}$ or some other metalloelement-dependent enzymes wherein the incorporation of $\mathrm{Mn}$ leads to a reduction in activity of non-Mn metalloelement-dependent enzymes requiring a metalloelement other than $\mathrm{Mn}$ for activation. 
Irradiation-Induced esophagitis, micro-ulceration, and esophageal stricture as well as cytokine mRNA elevations and squamous cell apoptosis were dramatically decreased in male $\mathrm{C} 3 \mathrm{H} / \mathrm{HeNsd}$ mice with intraesophageal instillation of mouse MnSOD-plasmid/liposome (SOD2-PL) $24 \mathrm{hr}$ before 35 or 37 Gy local esophageal $\mathrm{x}$-irradiation (58). Mice bearing orthostatic thoracic tumors treated with mouse SOD2-PL also evidenced esophageal transgenic SOD2 mRNA [102]. These results were suggested to provide support for human SOD2-PL gene therapy in a fractional irradiation paradigm to avoid acute and chronic radiationinduced side effects in a human clinical trial of pulmonary tumor irradiation [102]. Increased survival was also observed at both levels of irradiation. A significant increase in surviving fraction $(1.0, P=0.0291)$ versus 0.5 for control liposome treated mice was observed for $35 \mathrm{~Gy}$ irradiated mice treated with $100 \mu \mathrm{g}$ SOD2-PL/mouse given by the intra-esophageal route of administration with a significant $(P=0.015)$ decrease in esophagitis in this 30-day study. Mice irradiated with $37 \mathrm{~Gy}$ and treated with $200 \mu \mathrm{g}$ SOD2-PL/mouse or $10 \mu \mathrm{g}$ SOD2$\mathrm{PL} /$ mouse by intra-esophageal instillation experienced increased surviving fractions of $0.5(\mathrm{P}=0.05)$ or 0.7 ( $\mathrm{P}$ $=0.0119$ ) respectively compared to non-treated irradiated mice in this 60-day study [102]. While intra-trachael instillation of transgene before irradiation protected $\mathrm{C} 57 \mathrm{BL} / 6 \mathrm{~J}$ mice from whole-lung irradiation-induced alveolitis/fibrosis, there was no significant lung protection in SOD2-PL treated SP1-SOD2 or FeVB/NHsd transgenic mice. Over expression of either human SOD2 or murine Sod2 in the lungs of these transgenic mice did not provide local 11 to $15 \mathrm{~Gy}$ irradiated whole-lung or alveolar type II cell protection [103]. Over expression of SOD2 in SP-1 SOD2 mice may have made these mice more sensitive to radiation injury. However, these studies may have been seriously flawed since mice developing pulmonary distress were killed, preventing the possible observation that treated mice might have overcome this radiation-induced inflammatory complication.

\section{Radiation Protection and Recovery with Zinc Chelates.}

As pointed out in our earlier review [see 48] treatment with $\mathrm{Zn}$ compounds dramatically increased survival of lethally irradiated mice. In the interim it was shown that fractional whole-body $\gamma$-irradiation of male BALB/C mice given a total doses of $0.5,1$, or 1.5 Gy induced an increase in DNA-protein cross-links in the thymus, spleen, brain, and liver. However, when these mice were given drinking water containing $154 \mu \mathrm{M}$ $\mathrm{Zn}(\mathrm{II}) \mathrm{SO}_{4}$ for 30 days DNA-protein cross-links were dramatically decreased to levels observed in all of these tissues from non-irradiated mice [104].

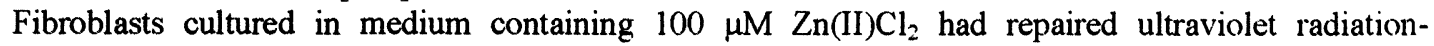
induced DNA strand-breaks and delayed in apoptotic loss of nucleosomes [105] Cells cultured with $100 \mu \mathrm{M}$ $\mathrm{Zn}(\mathrm{II}) \mathrm{Cl}_{2}$ and irradiated with $1.4,2.9,3.6$, or $5 \mathrm{~J} / \mathrm{cm}^{2}$ actually evidenced more double-stranded DNA than nonirradiated cells. This result suggests that $\mathrm{Zn}(\mathrm{II}) \mathrm{Cl}_{2}$ prevents and/or repairs DNA strand-breaks Similarly, apoptosis was always less in $\mathrm{Zn}(\mathrm{II}) \mathrm{Cl}_{2}$ supplemented cells at all times of measurement; $0,3,6,8,11,12$, and $18 \mathrm{hrs}$ after irradiation consistent with prevention and/or repair of irradiation-induced injury leading to apoptosis. Gamma irradiation-induced thymocyte DNA strand-breaks and apoptosis were synergistically decreased with combinations of $\mathrm{Zn}(\mathrm{II}) \mathrm{SO}_{4}$ and diethyldithiocarbamate, a compound known to form $\mathrm{Zn}(\mathrm{II})$ (diethyldithiocarbamate) ${ }_{2}[106]$.

Since addition of $\mathrm{Zn}(0.15 \mu \mathrm{M})$ to culture medium did not protect human melanoma cells through a radiation dose range of 1.5 to $8.0 \mathrm{~Gy}\left(0.85 \mathrm{~Gy} \mathrm{~min}^{-1}\right)$. It had been suggested earlier [see 48 ] that the protective effect of $\mathrm{Zn}$ was due to the facilitation of some homeostatic mechanism which was suggested to be induction of MT synthesis [see 48]. Studies of MT gene regulation identified the involvement of bacterial lipopolysaccharide, IL-1, interferon, and other immunostimulants with control of MT synthesis in the liver. These observations coupled with the observation that IL-1 has radioprotectant activity [54] support the hypothesis that MT synthesis has a role in reducing radiosensitivity. Induction of MT synthesis is a physiological response to oxidant stress as described for IL-1 or endotoxin-mediated responses to this stress as well as other cytokine-mediated responses to radiation injury $[58,59]$.

As pointed out earlier [see 48] $\mathrm{Zn}(\mathrm{II})(\text { aspartate })_{2}$ is known to have radioprotectant activity. An important question as to whether or not this compound protected neoplastic cells from radiation injury was answered when ip treatment with $90 \mu \mathrm{mol} \mathrm{kg} \mathrm{kg}^{-1} \mathrm{Zn}$ (II)(aspartate) $)_{2}$ did not inhibit $\gamma$-ray radiotherapcutic reduction of tumor volume using three adenocarcinomas of the colon or Ewings sarcoma implanted immunosuppressed mice [107]. Zinc(II)(aspartate)2 also significantly reduced radiation-induced decrease in hematocrit and thrombocyte, erythrocyte, and leukocyte numbers, an indication of spleen and/or bone marrow precursor cell sparing effect or rapid recovery of immunocompetence. $\mathrm{Zn}(\mathrm{II})$ (aspartate) 2 permitted a greater 
reduction in tumor volume than cysteamine [mercaptoethylamine (MEA)], AET, and WR-2721 and it was as effective as a syngeneic bone marrow transplant [107].

Doses of $90 \mu \mathrm{mol} \mathrm{Zn(II)(aspartate)} 2,80 \mu \mathrm{mol} \mathrm{Zn(II)(histidinate)} 2,80 \mu \mathrm{mol} \mathrm{Zn(II)(orotate)} 2$, or 122 $\mu \mathrm{mol} \mathrm{Zn(II)(acetate)})_{2} \mathrm{~kg}^{-1}$ given ip $3 \mathrm{hr}$ before irradiation ( 3.5 to $7.25 \mathrm{~Gy}$ ) facilitated post-irradiation recovery of hematocrit, thrombocytes, erythrocytes, and leukocytes in $\mathrm{C} 3 \mathrm{H}$ male and female mice [108]. Generally, $\mathrm{Zn}$ (II)(aspartate) 2 , was more effective than the other $\mathrm{Zn}$ chelates and administration along with WR-2721 produced a marked synergistic increase in recovery of hematocrit and thrombocytes. Zinc(II)(aspartate) ${ }_{2}$ was also the only $\mathrm{Zn}$ chelate that did not inhibit radiation-induced reduction in growth of adenocarcinomaimplanted and immunosuppressed mice [108].

Small non-toxic doses of $\mathrm{Zn}(\mathrm{II})(\text { aspartate })_{2}, 45 \mu \mathrm{mol} \mathrm{kg}{ }^{-1}$ ip, and WR-2721, $175 \mu \mathrm{mol} \mathrm{kg}^{-1}$ ip, given to female $\mathrm{C} 3 \mathrm{H}$ mice $30 \mathrm{~min}$ or $10 \mathrm{~min}$ before $\mathrm{LD}_{100 / 30} \gamma$-irradiation $\left(10.5 \mathrm{~Gy}, 0.2 \mathrm{~Gy} \mathrm{~min}^{-1}\right.$ ) produced a synergistic increase in survival of $83 \%$ versus $0 \%$ for vehicle-treated control mice [109]. Zinc(II)(aspartate) $45 \mu \mathrm{mol} \mathrm{kg}^{-1}$ ip, and WR-2721, 1,400 $\mu \mathrm{mol} \mathrm{kg}^{-1}$ ip, given to female C57BL/6 mice $30 \mathrm{~min}$ or $10 \mathrm{~min}$ before a fractionated $L D_{100 / 30} \gamma$-irradiation $(5 \times 1.9 \mathrm{~Gy}$ ) also produced a synergistic increase in survival of $83 \%$ versus $0 \%$ for vehicle-treated control mice. Fractionated whole body radiation-induced carcinogenesis leading to lymphoid tumors was dramatically decreased from $90 \%$ to $9 \%$ in C57BL/6 mice treated with $\mathrm{Zn}$ (II)(aspartate) $2,45 \mu \mathrm{mol} \mathrm{kg}{ }^{-1}$ ip, and WR-2721, 1,400 $\mu \mathrm{mol} \mathrm{kg}^{-1}$ given ip. Thus this combination treatment dramatically decreased radiation-induced lymphoid tumors [108].

The earlier review [see 48] pointed out that treatment with $60 \mu \mathrm{mol} \mathrm{Zn(II)})_{2}(3,5-\mathrm{DIPS})_{4} \mathrm{~kg}^{-1}$ produced $95 \%$ survival in $\mathrm{LD}_{50 / 30}\left(8 \mathrm{~Gy}, 1.55 \mathrm{~Gy} \mathrm{~min}^{-1}\right)$ irradiated male mice. Acute toxicity of this chelate was also due to CNS depression with a sedative-hypnotic dose of $123 \mu \mathrm{mol} \mathrm{kg}$. . However, the effective dose of $\mathrm{Zn}(\mathrm{II})_{2}(3,5-\mathrm{DIPS})_{4}$ was only $1 / 6$ of the acute toxic dose $381 \pm 75 \mu \mathrm{mol} \mathrm{kg}$.

\section{Mechanistic Modes of Zn Chelate Action.}

Since $\mathrm{Zn}$ chelates have no SOD-mimetic reactivity, activation or synthesis of $\mathrm{Cu}_{2} \mathrm{Zn}_{2} \mathrm{SOD}$, MT, or other $\mathrm{Zn}$-dependent enzymes including endonucleases and other known and suspected Zn-dependent transcription and translation processes [110] must at least partially account for their radioprotectant or radiorecovery activity. Another partial accounting may be attributed to protection of spleen and bone marrow stem cells by decreasing DNA replication and blockade in the $\mathrm{S}$ growth phase as observed for $\mathrm{CHO}$ cells treated with $\mathrm{Zn}(\mathrm{II}) \mathrm{Cl}_{2}$ as pointed out earlier [see 48 ].

A $100 \mu \mathrm{mol} \mathrm{kg}{ }^{-1}$ dose of $\mathrm{Zn}$ (II)-Desferrioxamine [Zn-DFO] produced $60 \%$ survival in whole body $\mathrm{LD}_{50 / 30} \gamma$-irradiated female $\mathrm{C} 3 \mathrm{H}$ mice treated $0.5 \mathrm{hr}$ before irradiation while Desferioxamine had no radioprotectant activity [111]. There was no radioprotective effect observed in studies of cultured V79 Chinese hamster cells. However, Zn-DFO concentration dependently prevented radiation-induced plasmid DNA strand-breaks through a concentration range of 0.5 to $2 \mathrm{mM}$.

Feeding an "antioxidant" diet containing $55 \mu \mathrm{mol} \mathrm{Zn(II)(gluconate)})_{2} \mathrm{~kg}^{-1}$ day $^{-1}$ to C57BL male mice for 45 days before irradiation( $6 \mathrm{~Gy}, 1.8 \mathrm{~Gy} \mathrm{~min}^{-1}$ ) caused an inhibition of TRPM-2, a marker gene for apoptosis expression both before and after irradiation [112]. The bcl-2 mRNA, which is involved in the prevention of apoptosis, and splenocyte number increased steadily after irradiation. The expression of sod-I gene increased and remained elevated for $24 \mathrm{hr}$, the last time of measurement after irradiation, and synthesis of the cat (catalase) gene increased slightly shortly after irradiation and decreased by $3 \mathrm{hr}$ after irradiation. Preliminary studies under the same experimental conditions revealed a decrease in frequency of radiationinduced mutations as evidenced by changes in the hypoxanthine-quanine phosphoribosyl-transferase locus of splenocytes from mice fed the antioxidant diet containing $\mathrm{Zn}(\mathrm{II})$ (gluconate) ${ }_{2}$. The maximum antimutagenic effect was detected by the $6^{\text {th }}$ week of diet administration.

\section{Radioprotectant and Radiorecovery Activity of Calcium-Channel Blockers.}

New evidence provided by Floersheim and his colleagues document radioprotectant and radiorecovery activities for some $\mathrm{Ca}$-channel blockers [113-116]. These reports are consistent with the earlier suggestion of Athar et al. [59] that Verapamil, a Ca-channel blocker, prevents radiation injury-induced conversion of Xanthine Dehydrogenase to Xanthine Oxidase, which synthesizes $\mathrm{O}_{2}$.

Diltiazem, a benzothiadiazepine $\mathrm{Ca}$-channel blocker, given sc as the hydrochloride salt in distilled water to female mice at doses of 61,122 , or $244 \mu \mathrm{mol} \mathrm{kg}{ }^{-1} 15 \min$ before $\mathrm{LD}_{100 / 30}\left(10.5 \mathrm{~Gy}, 0.15 \mathrm{~Gy} \mathrm{~min}{ }^{-1}\right)$ irradiation produced $17 \%, 58 \%$, or $93 \%$ survival [113]. A dose of $244 \mu \mathrm{mol} \mathrm{kg}{ }^{-1}$ given sc $10 \mathrm{~min}$ after irradiation produced $42 \%$ survival for this radiorecovery paradigm. Nifedipine, a dihydropyridine Ca-channel blocker, given ip at a dose of $4 \mu \mathrm{mol} \mathrm{kg}^{-1}$ in an ethanol vehicle, which provided $50 \mathrm{mmol}$ ethanol $\mathrm{kg}^{-1}, 30 \mathrm{~min}$ 
before $\mathrm{LD}_{100 / 30}$ irradiation $\left(8.5 \mathrm{~Gy}, 0.9 \mathrm{~Gy} \mathrm{~min}^{-1}\right.$ ) produced $100 \%$ survival and the vehicle produced $61 \%$ survival, a difference of $39 \%$ [113]. Treatment with $5 \mu \mathrm{mol} \mathrm{Nimodipine} \mathbf{k g}^{-1}$, another dihydropyridine Cachannel blocker, produced $82 \%$ survival whereas the vehicle containing $43 \mathrm{mmol}$ ethanol produced $42 \%$ survival. Distilled water-treated mice experienced $0 \%$ survival. Male mice treated ip with $10 \mu \mathrm{mol}$ Nimodipine $\mathrm{kg}^{-1} 30 \mathrm{~min}$ before $\mathrm{LD}_{100 / 30} 8.1 \mathrm{~Gy}\left(0.9 \mathrm{~Gy} \mathrm{~min}^{-1}\right)$ irradiation produced $75 \%$ survival while treatment with $9 \mu \mathrm{mol} \mathrm{kg}^{-1}$ ip Nifedipine (a dihydropyridine) produced $67 \%$ survival and the ethanol vehicle produced $30 \%$ survival. Injection of distilled water produced $0 \%$ survival. However, ip treatment with a dose of $10 \mu \mathrm{mol} \mathrm{kg} g^{-1}$ Nimodipine or $9 \mu \mathrm{mol} \mathrm{kg}^{-1}$ Nifedipine given before irradiation produced $58 \%$ survival while the group treated with the ethanol vehicle had $0 \%$ survival [113].

Isradipine, another dihydropyridine Ca-channel blocker, given at a dose of $74 \mu \mathrm{mol} \mathrm{kg}{ }^{-1}$ ip before irradiation (9 Gy) produced $58 \%$ survival. Treatment with $278 \mu \mathrm{mol} \mathrm{kg}{ }^{-1}$ Nitrendipine (a dihydropyridine Cachannel blocker), ip, produced $29 \%$ survival. Verapamil, a substituted aminopropylnitrile Ca-channel blocker, given at a dose of $35 \mu \mathrm{mol} \mathrm{kg}^{-1}$ ip and Flunarizine, a piperazine Ca-channel blocker, given before irradiation ( 9 Gy) at a dose of $62 \mu \mathrm{mol} \mathrm{kg}$ orally did not produce any increase in survival compared to the vehicle-treated group [113]. Based upon the efficacy of Verapamil in facilitating repair of photosensitization-radiation injury and its prevention of the XD to XO conversion as reported by Athar et al. [58,59], this mechanistic feature of Ca-channel blocker activity must be taken into account in examining their potential for radioprotectant activity. It would also be useful to examine this mechanistic aspect of all radiorecovery agents.

Floersheim suggested that Ca-channel blockers might also act by blockade of cell death due to $\mathrm{Ca}$ influx into cells following radiation injury [113]. However the antioxidative effects of Ca-channel blockers via scavenging of free radicals was suggested as an alternative mechanism of action, which could involve stable essential metalloelement chelate formation following hydrolysis of ester functional groups in vivo. Radical scavenging reactivity of aminothiol radioprotectants and formation of their disulfides was also suggested as a mechanism of their action in overcoming radical-mediated radiation injury [113]. A chelate mechanism for radical scavenging by aminothiols is also plausible. Variations in activity of Ca-channel blockers were suggested to be due to variations in bioavailability and receptor-bonding interaction [113].

Benzothiadiazepines and dihydropyridine $\mathrm{Ca}$-channel blockers may also serve as chelating agents and thus facilitate delivery of essential metalloelements to cells for de novo synthesis of essential metalloelementdependent repair enzymes. Calcium-Channel blockers have also been reported to decrease radiation-induced esophagitis as a consequence of thoracic irradiation. Variation in blood flow was proposed to explain the modified x-ray sensitivity of mouse tumor [113]. Calcium-Channel blocker-induced hypotension and tissue anoxia was negated as the cause of radioprotectant activity of these agents, since other agents causing these conditions had no radioprotecting activity [113]. Subsequently Floersheim reported [114] that $9 \mu \mathrm{mol}$ Nifedipine $\mathrm{kg}^{-1}$ given ip $3 \mathrm{hr}$ before $\mathrm{LD}_{100}$ irradiation $\left(9.8 \mathrm{~Gy}, 0.9 \mathrm{~Gy} \mathrm{~min}{ }^{-1}\right.$ ) produced $83 \%$ survival. Again, even though the radiation dose was a $\mathrm{LD}_{100 / 30}$ dose, the $96 \%$ ethanol vehicle produced $61 \%$ survival while an $18 \%$ ethanol vehicle produced $28 \%$ survival.

A dose of $244 \mu \mathrm{mol}$ Diltiazem hydrochloride $\mathrm{kg}^{-1}$ given sc to $\mathrm{LD}_{100 / 30}\left(10 \mathrm{~Gy}, 0.15 \mathrm{~Gy} \mathrm{~min}^{-1}\right)$ irradiated male $\mathrm{C} 3 \mathrm{H}$ mice produced $90 \%$ survival $(\mathrm{P}<0.005)$ with treatment $30 \mathrm{~min}$ before irradiation or $75 \%$ survival when given $10 \mathrm{~min}$ before irradiation. Treatment with $122 \mu \mathrm{mol} \mathrm{kg}^{-1}$ under these conditions and 30 min before irradiation produced $42 \%$ survival $(\mathrm{P}<0.01)$ compared to $8 \%$ survival for vehicle (distilled water)treated mice. When given ip at $244 \mu \mathrm{mol} \mathrm{kg}^{-1} 10$ min before irradiation there was $100 \%$ survival $(\mathrm{P}<0.005)$ but only $80 \%$ survival $(P<0.005)$ when given 30 minutes before irradiation compared to $17 \%$ survival for vehicle (distilled water)-treated mice. Treatment of female $\mathrm{C} 3 \mathrm{H}$ mice given a $10.5 \mathrm{~Gy}$ dose of irradiation and a dose of $244 \mu \mathrm{mol} \mathrm{kg}{ }^{-1}$ Diltiazem ip 10 min before irradiation produced $54 \%$ survival $(\mathrm{F}<0.005)$ compared with $2 \%$ survival for vehicle (distilled water)-treated mice (70). When these mice were treated $30 \mathrm{~min}$ before irradiation $59 \%$ survived $(\mathrm{P}<0.005)$. Treatment $120 \mathrm{~min}$ before irradiation produced only $19 \%$ survival $(\mathrm{P}<$ $0.025)$.

Diltiazem given in distilled water to $\mathrm{LD}_{100 / 30}\left(10 \mathrm{~Gy}, 15 \mathrm{cGy} \mathrm{min}^{-1}\right)$ irradiated female BALB/c mice before treatment with $244 \mu \mathrm{mol} \mathrm{kg}^{-1}$ ip or sc produced $100 \%$ survival $(\mathrm{P}<0.005)$ compared to vehicle-treated mice. The same $244 \mu \mathrm{mol} \mathrm{kg} \mathrm{kg}^{-1}$ dose given sc or ip to $\mathrm{C} 57 \mathrm{BL} 6, \mathrm{NMRI}$, or MAG mice produced significant $(\mathrm{P} \leq$ 0.01 ) strain-related differences in efficacy: $100 \%, 67 \%$, or $8 \%$ survival respectively [114].

Nifedipine given $30 \mathrm{~min}$ before irradiation at doses of $2.3,4.5$, or $9 \mu \mathrm{mol} \mathrm{kg}{ }^{-1}$ ip to $\mathrm{LD}_{100 / 30}(10.5 \mathrm{~Gy}$, $\left.0.15 \mathrm{~Gy} \mathrm{~min}^{-1}\right)$ irradiated female $\mathrm{C} 3 \mathrm{H}$ mice produced $0 \%, 40 \%$, or $79 \%(\mathrm{P} \leq 0.05)$ survival, respectively, compared to $6 \%$ survival for ethanol vehicle-treated control mice [114]. Nitrendipine given at doses of 139 or $278 \mu \mathrm{mol} \mathrm{kg}{ }^{-1}$ ip in distilled water to these mice $30 \mathrm{~min}$ before irradiation produced significant $(\mathrm{P}<0.005)$ increases of $25 \%$ or $29 \%$ survival respectively. When they were given $120 \mathrm{~min}$ before irradiation they 
produced $22 \%$ or $30 \%$ survival $(\mathrm{P} \leq 0.01)$ versus $0 \%$ survival for distilled water-treated control mice [114]. Verapamil, given to these mice at doses of $35 \mu \mathrm{mol} \mathrm{kg}{ }^{-1}$ ip or Flunarizine, a piperazine Ca-channel blocker, given to these mice at doses of $62 \mu \mathrm{mol} \mathrm{kg}{ }^{-1}$ ip at 30 or 120 min after irradiation did not produce any increase in survival compared to the $0 \%$ survival for vehicle-treated mice [114].

Combinations of $61,91,122$, or $244 \mu \mathrm{mol} \mathrm{kg}{ }^{-1}$ Diltiazem and $7.5,15,30,45$, or $91 \mu \mathrm{mol} \mathrm{kg} \mathrm{kg}^{-1}$ $\mathrm{Zn}$ (II)(aspartate) ${ }_{2}$ given to female $\mathrm{C} 3 \mathrm{H}$ mice before irradiation were studied in a factorial designed experiment. Survivals for Diltiazem-treated mice were $33 \%, 44 \%$, or $91 \%$ respectively while only the $91 \mu \mathrm{mol} \mathrm{kg}{ }^{-1}$ dose of $\mathrm{Zn}(\mathrm{II})(\text { aspartate) })_{2}$ was effective and produced $92 \%$ survival in these $\mathrm{LD}_{100 / 30}\left(10.5 \mathrm{~Gy}, 0.15 \mathrm{~Gy} \mathrm{~min}^{-1}\right)$ irradiated mice. However survival increased for nearly all combinations of Diltiazem and $45 \mu \mathrm{mol} \mathrm{kg}$ $\mathrm{Zn}(\mathrm{II})(\text { aspartate) })_{2}$ to $50 \%, 100 \%$, or $92 \%$ [114].

Combinations of Diltiazem and Nifedipine were also studied using the factorial paradigm. A synergistic increase in survival was found for increasing active doses of Nifedipine and Diltiazem from 61 to $122 \mu \mathrm{mol} \mathrm{kg}^{-1}$ when given before irradiation [114]. No synergism was found for combinations of active doses of Diltiazem, Nitrendipine, or Nifedipine and WR-2721. Synergism was observed for combinations of Diltiazem ranging from $7.5,15,30,61$, or $122 \mu \mathrm{mol} \mathrm{kg}^{-1}$ and $17.5,26$, or $35 \mathrm{mmol}$ DMSO kg ${ }^{-1}$, reaching $100 \%$ survival for combinations of $122 \mu \mathrm{mol} \mathrm{kg}{ }^{-1}$ Diltiazem and $17.5,26$, or $35 \mathrm{mmol} \mathrm{DMSO} \mathrm{\textrm {kg } ^ { - 1 }}$ in $\mathrm{LD}_{100 / 30}$ irradiated $\mathrm{C} 3 \mathrm{H}$ mice treated before irradiation [114].

Koch [115] suggested that enhanced local blood flow caused by Ca-channel blockers might be responsible for increased radiosensitivity due to the oxygen effect. The exchange by Koch [115] and Floersheim [116] offered a number of speculations concerning Ca-channel blockade in radiosensitization and radioprotection. These related to dose, chemical class, a possible role for small molecular mass solvent molecules, as well as effects on metabolizing enzymes.

Interestingly, calcium was found to be elevated in heart, liver, lung, spleen, and kidney of adult male albino rats but decreased in these tissues of female rats two months after 5 Gy $\gamma$-irradiation [117]. While cardiac $\mathrm{Fe}$ was elevated, $\mathrm{Fe}$ content decreased in all other tissues of male rats. There were no changes in heart and lung $\mathrm{Fe}$ in female rats while liver, spleen, and kidney content decreased in female rats. Zinc was elevated in the heart, decreased in lung and spleen, and unchanged in liver and kidney of both male and female rats [117].

\section{Radioprotectant Activity of Serotonin and Acyl Melatonin Homologs.}

A review of Melatonin, N-acetyl-5-methoxytryptamine, antioxidant effects pointed out that Melatonin is relatively non-toxic and protects against ionizing radiation injury [118]. This review cited the report of Blickenstaff et al. [119] as having shown that Melatonin, the acetylated methoxyether of Serotonin, 5hydroxytryptamine, produced $75 \%$ survival in $\mathrm{LD}_{100 / 30} 9.5$ Gy whole-body irradiated male Swiss ND4 mice. This was an increase in radiation protection compared to Serotonin, which produced only $20 \%$ survival in the same study. Intraperitoneal treatment of these mice with soybean oil solutions or suspensions of $1.1 \mathrm{mmol} \mathrm{kg}^{-1}$ acetyl (Melatonin), propionyl, butanoyl, pentanoyl, hexanoyl, octanoyl, decanoyl, or hexadecanoyl analogs of 5 -methyltryptamine 30 min before irradiation produced survivals of $0 \%, 43 \%(P=0.0045), 32 \%, 75 \%, 95$ $\%, 65 \%$, or $48 \%$ respectively. In this experimental paradigm a 0.78 mmol WR-2721 kg-1 treatment produced $50 \%$ survival. Radioprotectant activities of all Melatonin analogs were significantly different from vehicletreated mice and the activity of Melatonin was about equal to that of WR-2721. The increase in radioprotectant activity was greatest for the hexanoyl and octanoyl derivatives, showing an increase in activity with increasing lipophilicity. However, further increasing lipophilicity with the formation of still longer chain amides lead to a decrease in activity, as is usually the case when lipophilicity is increased beyond some optimal value. The observed radioprotectant potency as well as a lack of Melatonin toxicity was suggested to support further study of Melatonin and these acyl homologs in circumstances of human radiation injury [118].

These compounds can participate in coordinate-covalent bond formation with essential metalloelements. The considerable enolic character of the amide carbonyl group and the proximity of the weakly acidic indole amine offer possible coordination sites.

Vijayalaxmi et al. found that treatment $1 \mathrm{hr}$ before $\mathrm{LD}_{50 / 30} 8.15 \mathrm{~Gy}$ whole-body irradiation with ip doses of 0.55 or $1.1 \mathrm{mmol}$ Melatonin $\mathrm{kg}^{-1}$ suspended in soybean oil produced survivals of $50 \%$ or $85 \%(\mathrm{P}=$ 0.0080 ) respectively in CD2 mice versus $50 \%$ survival for vehicle-treated mice [120].

Karbownic et al. [121] recently reported that $440 \mu \mathrm{mol}$ Melatonin $\mathrm{kg}^{-1}$ given as a soybean oil suspension ip to male Sprague-Dawley rats four times at 120,90,60, and $30 \mathrm{~min}$ before whole-body 8 Gy irradiation completely prevented the formation of 8-hydroxy-2'-deoxyguanosine and microsomal membrane rigidity in hepatocytes. Both of these damages are consequences of ionizing irradiation due to DNA or protein 
and lipid damage. It is noteworthy that these repairs of radiation injury were observed as soon as $12 \mathrm{hr}$ after treatment and irradiation.

\section{Radioprotectant Activity of Substituted Anilines.}

Using the same experimental paradigm that allowed the observation of radioprotectant activity for Melatonin homologs, Blickenstaff et al. [122] found that a series of substituted anilines had radioprotectant activity. Intraperitoneal treatment of male Swiss ND4 mice with soybean oil solutions or suspensions of 780 $\mu \mathrm{mol} \mathrm{kg} \mathrm{kg}^{-1}$ 4-aminobenzophenone, 4-aminopropiophenone, or the ethyl ketal of 4-aminopropiophenone derivatives of aniline $30 \mathrm{~min}$ before $\mathrm{LD}_{100 / 30} 9.5 \mathrm{~Gy}$ irradiation produced survivals of $100 \%, 100 \%$ or $95 \%$ respectively versus $4 \%$ survival for vehicle-treated mice. This radioprotectant paradigm also revealed a range of $88 \%$ to $55 \%$ survivals for $780 \mu \mathrm{mol} \mathrm{kg}{ }^{-1}$ treatments using: 4-Br; 4-CN; 3-Br; 4-NO $\mathrm{NO}_{2}$ 4- $\mathrm{COCH}_{3} ; 4-\mathrm{Cl}, 2-$ $\mathrm{CF}_{3} ; 4-\mathrm{Cl}, 3-\mathrm{NO}_{2} ; 4-\mathrm{CO}_{2} \mathrm{CH}_{3} ; 3-\mathrm{Cl} ; 4-\mathrm{Cl} ; 4-\mathrm{CF}_{3} ; 4-\mathrm{SCH}_{3} ; 4-\mathrm{I}$; and 4-Cl, 3- $\mathrm{CF}_{3}$ substituted anilines, survivals ranged from $40 \%$ down to $5 \%$ for 3,4-diCl; $\mathrm{H}$ (aniline); 4- $\mathrm{NH}_{2} ; 4-\mathrm{CH}_{3} ; 4-\mathrm{CONH}_{2} ; 4-\mathrm{Cl}, 2-\mathrm{NO}_{2}$; 4-Cl,2$\mathrm{CO}_{2} \mathrm{H} ; 4-\mathrm{COC}_{6} \mathrm{H}_{4} \mathrm{NH}_{2} ; 4-\mathrm{CH}_{2} \mathrm{CH}_{2} \mathrm{OH}$; 4-CONHNH${ }_{2} ; 4-\mathrm{OH} ; 4-\mathrm{Cl}, 2-\mathrm{OCH}_{3}, 5-\mathrm{CH}_{3}$; and 4-F substituted anilines, and $0 \%$ survival for 2- $\mathrm{Cl} ; 2-\mathrm{Br} ; 3,4,5-\mathrm{triCl}$; and $2-\mathrm{COC}_{6} \mathrm{H}_{5}, 4-\mathrm{Cl}$ substituted anilines [122].

In addition, Blickenstaff et al. [122] reported $95 \%$ survival for $780 \mu \mathrm{mol} \mathrm{kg}^{-1} 2-\mathrm{NH}_{2}, 5-\mathrm{Cl}$-pyriding and 2-Cl,5- $\mathrm{NH}_{2}$-pyridine treated mice, $79 \%$ survival for 2- $\mathrm{NH}_{2}, 5-\mathrm{Br}$-pyridine treated mice; $5 \%$ survival for 2 $\mathrm{NH}_{2}, 4-\mathrm{CH}_{3}, 6-\mathrm{OH}$-pyrimidine treated mice, $67 \%$ survival for 5-Cl-1,2,3-benzotriazole treated mice, $20 \%$ survival for 2,6-diNH 2 -9,10-anthraquinone treated mice, $14 \%$ survival for 1- $\mathrm{NH}_{2}, 4-\mathrm{Cl}$-napthalene treated mice, and quite interestingly, $0 \%$ survival for 4-Cl-acetylaniline treated mice even though the non-acetylated compound produced $68 \%$ survival.

These substituted anilines represent an interesting class of radioprotectants. Their potential for influencing essential metalloelement metabolism in facilitating repair of radiation injury remains to be explained. Amino group sulfation or glucuronide formation offer potential pathways for the formation of ligands capable of acting as chelating agents in facilitating tissue distribution of essential metalloelements needed for de novo syntheses of essential metalloelement dependent enzymes required for repair of radiation injury.

\section{Radioprotectant Activity of Curcumin.}

Curcumin, a $\beta$-diketone $\{1,7$-bis(4'-hydroxy-3'-methoxyphenyl)-1,6-heptadiene-3,5-dione $\}$, is a yellow major component of Turmeric, a spice prepared from dried rhizomes of Curcuma longa L. Tumeric is widely used to season foods in Asian countries and in particular, Indian Curry. It is of particular interest to note that Curcuma longa $\mathrm{L}$ is a fungus and fungi are well known for their high copper content. Since $\beta$ diketones are well known chelating agents $[123,124]$ and this fully conjugated $\beta$-diketone is likely to form particularly stable $\mathrm{Cu}$ chelates as a result of the extended conjugation in this ligand, it may be that this ligand exists as a $\mathrm{Cu}(\mathrm{II})$ chelate in fungi.

In 1993 Abraham, Sarma and Kesavan reported that Curcumin decreased chromosomal damage in $\gamma$ irradiated mice [125]. A single oral administration of $27.2 \mu \mathrm{mol}$ Curcumin $\mathrm{kg}^{-1}$ to male Swiss albino mice $2 \mathrm{hr}$ after whole-body 1.15 Gy irradiation significantly $(\mathrm{P}=0.01)$ reduced frequencies of micronucleated polychromatic erythrocytes (MPCEs) in bone marrow samples taken $24 \mathrm{hr}$ after irradiation. Oral administration of $13.6,27.2$, or $54.4 \mu \mathrm{mol}$ Curcumin $\mathrm{kg}^{-1} 2 \mathrm{hr}$ before irradiation produced a dose related decrease in MPCEs in bone marrow samples taken $24 \mathrm{hr}$ after irradiation. Oral treatment with $27.2 \mu \mathrm{mol}$ Curcumin $\mathrm{kg}^{-1} 2 \mathrm{hr}$ before irradiation produced significant $(\mathrm{P}=0.05$ to 0.01$)$ time-dependent decreases in MPCEs in bone marrow samples taken 24, 30, and $48 \mathrm{hr}$ after irradiation. These results suggest that Curcumin is useful in facilitating recovery from radiation injury.

Subsequently, Inano et al. [126] reported that feeding Curcumin decreased the incidence of mammary tumor in rats. A $1 \%$ Curcumin diet fed to 2.6 Gy whole-body irradiated pregnant Wistar-MS rats just prior to pup birth (a mammary tumor initiating procedure) and then implanted with diethylstilbestrol sustained release pellets for 12 mo following weaning (a mammary tumor promoter regimen) caused a dramatically decreased incidence of mammary tumor. Tumor formation decreased from $84.6 \%$ for the control diet fed group versus a $28 \%$ incidence for the Curcumin fed rats. Feeding the diet containing Curcumin significantly $(\mathrm{P}<0.001)$ reduced the number of rats with tumors and the number of tumors per rat and increased the latency period for mammary tumor formation $(\mathrm{P}<01001)$. Using this same pregnant Wistar-MS rat model of mammary tumorogenesis and feeding a $1 \%$ Curcumin diet for a brief period from day-11 of pregnancy to day-23, the day of birth, with 1.5 Gy whole-body irradiation on day-20, prior to hirth of the rat pups, again significantly 
$(\mathrm{P}<0.0001)$ decreased the number of dams with mammary tumors from 19 (70.3\% incidence) for the control group to 5 (18.5\% incidence) for the Curcumin fed rats. This Curcumin diet protocol also significantly $(\mathrm{P}<0.0001)$ delayed development of mammary tumors in Curcumin fed rats. Eventually mammary tumors did develop during the last two months of this 12-mo study [127]. Curcumin was fed for only 10 days in this study while it was fed for $1 \mathrm{yr}$ in the first study (82). Thus further documenting and extending the application of dietary Curcumin in preventing irradiation-induced mammary tumors.

\section{CONCLUSIONS}

Understanding essential metalloelement metabolism and its role in responding to radiation injury as mediated by immunomodulating cytokines does offer a renewed and potentially more effective approach to recovery from all radiation syndromes. Copper, $\mathrm{Fe}, \mathrm{Mn}$, and $\mathrm{Zn}$ chelates have radioprotectant activity based upon results obtained with treatment before radiation injury and some have been observed to have radiorecovery activity based upon results obtained with treatment after radiation injury. These compounds do not prevent radiation injury however they do facilitate repair and recovery from radiation injury. They are also far less toxic than existing radioprotectants. Existing radioprotectants have not been to shown to have radiorecovery activity. New chelates with increased efficacy and still less toxicity may be found using imaginative synthetic approaches to new ligands based upon existing compounds such as amino acids, salicylates, as well as radioprotectant aminothiols Ca-channel blockers, acyl Melatonin analogs, substituted anilines, and Curcumin. These chelates will also have potential for improving therapies of inflammatory diseases, ulcers, seizures, neoplastic diseases, diabetes, and pathology associated with ischemia-reperfusion

Combination treatment with essential metalloelement chelates and aminothiols, Ca-channel blockers, acyl Melatonin homologs, substituted anilines, and $\beta$-diketones such as Curcumin also offer an approach to improving radiation recovery and treatment of other recognized disease states. Combinations of some of these agents with essential metalloelement chelates may lead to the development of new physiological, biochemical, and pharmacological approaches to overcoming many disease states.

\section{ACKNOWLEDGEMENT}

We are indebted to the National Institute for General Medical Sciences, PHS grant number S06-RR08211 for financial support.

\section{REFERENCES}

[1] I.H. Tipton, M.J. Cook. Health Phys., 1, (1963) 103.

[2] G.V. Iyengar, W.E. Kollmer, J.M. Bowen. The Elemental Composition of Human Tissues and Body Fluids, Springer, New York, (1978).

[3] P.M. May, D.R. Williams. FEBS Lett. 78, (1977) 134.

[4] J.R.J. Sorenson. Prog. Med. Chem. 26, (1989) 437.

[5] E.L. Smith, R.L. Hill, I.R. Lehman, R.J. Lefkowitz, P. Handler, A. White. Seventh Edition Principals of Biochemistry: General Aspects and Mammalian Biochemistry. McGraw-Hill, New York, (1983).

[6] J.R. Prohaska. In "Essential and Toxic Trace Elements in Human Health and Disease", (A.S. Prasad, Ed.); Alan R. Liss, New York, (1988) 105.

[7] R.E. Mains, B.A. Eipper, C.C. Glembotski, R.M. Dores. Trends Neuro. Sci. 6 (1983) 229.

[8] E. Weber, F.S. Esch, P. Bohlen, S. Paterson, A.D. Corbett, A.T. McKnight, H.W.

Kosterlitz, J.D. Barchas, C.J. Evans. Proc. Natl. Acad. Sci. 80 (1983) 7362.

[9] D.C. Liebisch, B.R. Seizinger, G. Michael, A. Herz. Neurochem. 45 (1985) 1495.

[10] A. Bianchini, G. Musci, L. Calabrese. J. Biol. Chem. 274 (1999) 20265.

[11] J. Collinge, M.A. Whittington, K.C.L. Sidle, C.J. Smith, M.S. Palmer, A.R. Clarke, G.R. Jefferys. Nature 370 (1994) 295.

[12] T. Tamura, K.J. Hong, Y. Mizuno, K.E. Johnston, C.L. Keen. Biochim. Biophys. Acta 1427 (1999)

351.

[13] T. Borchardt, J. Camakaris, R. Cappai, C.L. Masters, K. Beyreuther, G. Multhaup. Biochem. J. 344 (1999) 461.

[14] K. Sekiya, H. Nagasaki, N. Ozaki, A. Suzuki, Y. Miura, Y. Oiso. Biochem. Biophys. Res. Comm. 278 (2000) 211.

[15] L. Rossi, M.R. Ciriolo, E. Marchese, A. De Martino, M. Giorgi, G. Rotilio. Biochem. Biophys. Res. Comm. 203 (1994) 1028.

[16] A.L. Lamb, A.S. Torres, T.V. O’Halloran, A.C. Rosenzweg. Biochem. 39 (2000) 14720. 
[17] D.L. Huffman, T.V. O'Halloran. J. Biol. Chem. 275 (2000) 18611.

[18] A.L. Lamb, A.K. Wernimont, R.A. Pufahl, T.V. O'Halloran, A.C. Rosenzweig. Biochem. 39 (2000)

1589.

[19] S.X. Liu, J.P. Fabisiak, V.A. Tyurin, G.G. Borisenko, B.R. Pit, J.S. Lazo, V.E. Kagan. Chem. Res. Toxicol. 13 (2000) 922.

[20] A. Baba, T. Kihara, E. Lee, H. Iwata. Biochem. Pharmacol. 30 (1981) 171.

[21] A. White, K.M. Crawford, C.S. Patt, P.J. Lad. J. Biol. Chem. 251 (1976) 7304.

[22] R. Gerzer, E. Bohme, F. Hofmann, G. Schultz. FEBS Lett. 132 (1981) 71.

[23] O. Halevy, D.A. Sklan. Life Sci. 34 (1984) 1945.

[24] V.C. Culotta, T. Hsu, S. Hu, P. Furst, D. Hamer. Proc. Natl. Acad. Sci. 86 (1989) 8377.

[25] P. Klatt, K. Schmidt, G. Uray, B. Mayer. J. Biol. Chem. 268 (1993) 14781.

[26] G.D. Lawrence, D.T. Sawyer. Coord. Chem. Revs. 27 (1978) 173.

[27] M. Korc in "Essential and Toxic Trace Elements in Human Health and Disease". (A.S. Prasad, Ed.).

Alan R. Liss, New York (1988) 253.

[28] V.L. Schramm, F.C. Wedler. Manganese in Metabolism and Enzyme Function. Academic Press, New York. 1986.

[29] E.J. Neer. J. Biol. Chem. 254 (1979) 2089.

[30] R.M. Leach,Jr. Fed. Proced. 30 (1971) 991.

[31] R. Myllyla, H. Anttinen, K.I. Kivirikko. Euro. J. Biochem. 101 (1979) 261.

[32] "Metal Ions in Biological Systems: Manganese and its role in biological processes Volume 37. (A. Sigel and H. Sigel. Eds.), Marcel Dekker, New York (2000)

[33] G. Westin, W. Shaffner. Nucl. Acid Res. 16 (1988) 5771.

[34] A. Klug, D. Rhodes. Cold Spring Harbor Symp. in Quant. Biol. 52 (1987) 473.

[35] L. Ravanti, V.M. Kahari. Internat. J. Molec. Med. 6 (2000) 391.

[36] A.A.D. Maur, T. Belser, Y. Wang, C. Gunes, P. Lichtlen, O. Georgiev, W. Schaffner, Cell Stress Chaper. 5 (2000) 196.

[37] L.M. Klevay, in "Role of Copper in Lipid Metabolism." (K.Y. Lei, and T.P. Carr. Eds.), CRC Press, Boca Raton, (1990) 233.

[38] H.S. Wright, H.A. Guthrie, M.-Q. Wong, V. Bernardo. Nutr. Today 26 (1991) 21.

[39] J.R.J. Sorenson. Inorg. Perspec. Biol. Med., 2 (1978) 1.

[40] M. Srivastava, R.K. Kale. Rad. Res. 152 (1999) 257.

[41] J.A. Fee, J.S. Valentine in "Superoxide and Superoxide Dismutases." (A.M.;Michelson, J.M. McCord, I. Fridovich Eds.) Academic Press, New York (1977) 19.

[42] E.J. Corey, M. Mehrota, A.U. Khan. Biochem. Biophys. Res. Comm. 145 (1987) 842.

[43] K.N. Prasad in "Radiation Biology." (D.J. Pizzarelli and L.G. Colombetti, Eds.) CRC Press, Boca Raton (1982) 205.

[44] D. Harrison, M. Ricciardello, L. Collins. Aust NZ J. Med. 28 (1998) 597.

[45] J.B. Little. Carcinogenesis 21 (2000) 397.

[46] J. Chatterjee, K. De, S.K. Basu, A.K. Das. Indian J. Med. Res. [B] 98 (1993) 243.

[47] A. Petrova, T. Gnedko, I. Maistrova, M. Zafranskaya, N. Dainiak. Stem Cells 15 (suppl 2) (1997) 141.

[48] J.R.J., Sorenson, L.S.F., Soderberg, L.W. Chang. Soc. Exp. Bio.l Med. 210 (1995) 191.

[49] R.D. Henderson, T.D. Henderson, H.J. Irving, J.R.J. Sorenson. Metal-Based Drugs 6 (1999) 121.

[50] H.J. Irving, T.D. Henderson, R.D. Henderson, E.L. Williams, W.M. Willingham, J.R.J. Sorenson. Inflammopharmacol. 3 (1995) 251.

[51] M. Zhou, J.R.J. Sorenson. J. Inorg. Biochem. 72 (1998) 217.

[52 J.A. Kuykendall III, H. Simmons III, H.J. Irving, M.A. Wear, P.G. Sorenson, L.G. Tipton, K.M. Maddox, E.L. Williams, V.A. Pham-Tran, C. Credit, I.L. Chowdhury, S. Khan, J.B. Tipton, W.M. Willingham, J.R.J. Sorenson. Metal-Based Drugs 6 (1999) 135.

[53] D. Murry, W.H. McBride in "Radioprotective agents. Kirk-Othmer Encyclopedia of Chemical Technologv, Fourth Edition, Volume 20" (1996) 963.

[54] R. Neta. Modulation of radiation damage by cytokines. Stem Cells 15 (suppl 2) (1997) 87.

[55] C. Petit-Frère, E. Capulas, D.A. Lyon, C.J. Norbury, J.E. Lowe, P.H. Clingen, E. Riballo, M.H.L. Green, C.F. Arlett. Carcinogenesis 21 (2000) 1087.

[56] A.A.I. Daffada, S.P. Young. FEBS Lett. 457 (1999) 214.

[57] J.R.J. Sorenson. Prog. Med. Chem. 26 (1989) 437. 
[58] M. Athar, H. Mukhtar, C.A. Elmets, M.T. Zaim, J.R. Lloyd, D.R. Bickers. Biochem. Biophys. Res. Comm. 151 (1988) 1054.

[59] M. Athar, C.A. Elmets, D.R. Bickers, H. Mukhtar. J. Clin. Invest. 83 (1989) 1137.

[60] K. Danno, T. Horio, M. Takigawa, S. Imamura. J. Invest. Dermatol. 83 (1984) 166.

[61] G. Deliconstantinos, V. Villiotou, C. Fassitsas. J. Cardiovas. Pharmacol. 20(suppl 12) (1992) S63.

[62] Y. Miyachi, S. Imamuara, Y. Niwa. J. Invest. Dermatol. 89 (1987) 111.

[63] Y. Hashimoto, N. Ohkuma, H. lizuka. Arch. Dermatol. Res. 283 (1991) 317.

[64] D.L. Bissett, R. Chatterjee, D.P. Hannon. J. Soc. Cosmet. Chem. 43 (1992) 85.

[65] A. Keshavarzian, J. Haydek, R. Zabihi, M. Doria, M. D'Astice, J.R.J. Sorenson. Digest. Dis. Sci. 37 (1992) 1866.

[66] J. Chatterjee, K. De, S.K. Basu, A.K. Das. Indian J. Med. Res. [B] 98 (1993) 243.

[67] J.-L. Lefaix, S. Delanian, J.-J. Leplat, Y. Tricaud, M. Martin, A. Nimrod, F. Baillet, F. Daburon. Int. J. Radiat. Oncol. Biol. Phys. 35 (1996) 305.

[68] J. Sun, Y. Chen, M. Li, Z. Ge. Free Rad. Biol. Med. 24 (1998) 586.

[69] T.V. O'Halloran in "Metal Ions in Biological Systems. Metalloregulatory proteins: Metal-Responsive molecular switches governing gene expression." (H. Sigel and A. Sigel Eds.), New York, Marcel Dekker Inc. (1989) 105.

[70] G.S. Naeve, A.M. Vana, J.R. Eggold, G.S. Kelner, R. Maki, E.B. Desouza, A.C. Foster. Neurosci. 93 (1999) 1179.

[71] G.S. Kelner, M.-H. Lee, M.E. Clark, D. Maciejewski, D. McGrath, S. Rabizadeh, T. Lyons, D. Bredesen, P. Jenner, R.A. Maki. J. Biol. Chem. 275 (2000) 580.

[72] J.E. Swauger, P.M. Dolan, J.L. Zeier, P. Kuppusamy, T.W. Kensler. Chem. Res. Toxicol. 4 (1991) 223.

[73] C.J. Reed, K.T. Douglas. Biochem. J. 275 (1991) 601.

[74] A.S. Modak, J.K. Gard, M.C. Merriman, K.A. Winkler, J.K. Bashkin, M.K. Stern. J. Am. Chem. Soc. 113 (1991) 283.

[75] L.A. Basile, J.K. Barton. in "Metal Ions in Biological Systems, Metallonucleases: Real and Artificial." (H. Sigel and A. Sigel, Eds.), New York, Marcel Dekker Inc., (1989) 31.

[76] S. Borah, M.S. Melvin, N. Lindquist. R.A. Manderville. J. Am. Chem. Soc. 120 (1998) 4557.

[77] J. Baquial, J.R.J. Sorenson. J. Inorg. Biochem. 47 (1992) 59.

[78] S.T. Shuff, P. Chowdhary, M.F. Khan, J.R.J. Sorenson. Biochem. Pharmacol. 43 (1992) 1601.

[79] F.T. Greenaway, J.J. Hahn, N. Xi, J.R.J. Sorenson. Biometals 11 (1998) 21.

[80] J.R.J. Sorenson. J. Inorg. Biochem. 43 (1991) 625.

[81] A.T. Gurbuz, J. Kunzelman, E.E. Ratzer. J. Surg. Res. 74 (1998) 149.

[82] J.G.L. Baquial, J.R.J. Sorenson. Inorg. Biochem. 60 (1995) 133.

[83] B.L. Booth, E. Pitters, B. Mayer, J.R.J. Sorenson. Metal-Based Drugs 6 (1999) 111.

[84] A. Bianchini, G. Musci, L. Calabrese. J. Biol. Chem. 274 (1999) 20265.

[85] D. Jourd heuil, F.S. Laroux, D. Kang, A.M. Miles, D.A. Wink, M.B. Grisham. Meth. Enzymol. 301 (1999) 220.

[86] I.G. Kim, S.Y. Park. FEBS Lett. 437 (1998) 293.

[87] M.-K. Cha, I.-H. Kim. Biochem. 38 (1999) 12104.

[88] J.W. Tams, A.H. Johnsen, J. Fahrenkrug. Biochem. J. 341 (1999) 271.

[89] B.A. Eipper, D.A. Stoffers, R.E. Mains. Ann. Rev. Neurosci. 15 (1992) 57.

[90] K. Sekiya, H. Nagasaki, N. Ozaki, A. Suzuki. Biochem. Biophys. Res. Comm. 278 (2000) 211.

[91] H.J. Irving, M.A. Wear, H. Simmons, L.G. Tipton, J.B. Tipton, K.M. Maddox, W.M. Willingham, J.R.J. Sorenson. Inflammopharmacol. 4 (1996) 309.

[92] W.C. Hunt, R.A. Sorrenti, M.E. Renke, L.Y. Xie, E.M. Waterfield, J.G. Levy. Immunopharmacol. Immunotoxicol. 16 (1994) 55.

[93] R. Murata, Y. Nishimura, M. Hiraoka, M. Abe, M. Satoh. Manganese chloride treatment does not protect against acute radiation injury of skin or crypt cells. Radiat. Res. 143 (1995) 316.

[94] T.D. Henderson, R.D. Henderson, H.J. Irving, W.M. Willingham, J.R.J. Sorenson.

Inflammopharmacol. 3 (1995) 241.

[95] V. Chhajlani, K.L. Axelsson, J. Ahlner, J.E.S. Wikberg. Biochem. Internatl. 19 (1989) 1039.

[96] B. Ortel, R.W. Gange, T. Hasan. J. Photochem. B:Biol. 7 (1990) 261.

[97] S.M. Hahn, A. Krishna, J.B. Mitchell, A. Russo. Arch. Biochem. Biophys. 288 (1991) 215.

[98] D.J. Darr, S. Yanni, S.R. Pinnell. Free Rad. Biol. Med. 4 (1988) 357.

[99] D. Darr, K.A. Zarilla, I. Fridovich. Arch. Biochem. Biophys. 258 (1987) 351. 
[100] J.S.L. Mok, K. Paisley, W. Martin. Brit. J. Pharmacol. 124 (1998) 111.

[101] J.A. Kuykendall III, R.H. Ebert II, I.H. El-Sayed, P.K. Roberson, V.A. Pham-Tran, B.L. Booth, T. Brooks, W.M. Willingham, J.R.J. Sorenson. Metal-Based Drugs 6 (1999) 127.

[102] M.W. Epperly, J.A. Gretton, S.J. DeFilippi, C.A. Sikora, D. Liggit, G. Koe, J.S. Greenberger. Rad. Res. 155 (2001) 2.

[103] M.W. Epperly, E.L. Travis, J.A. Whitsett, I. Raineri, C.J. Epstein, J.S. Greenberger. Internat. J. Cancer 96 (2001) 11.

[104] A.N. Osipov, V.D. Sypin, G.Ya. Kolomijtseva. Biochem (Moscow) 64 (1999) 201.

[105] M.-T. Leccia, M.-J. Richard, A. Favier, J.C. Béani. Biol. Trace Elem. Res. 69 (1999) 177.

[106] J. Mathieu, S. Ferlat, D. Ferrand, B. Ballester, S. Platel, V. Gerard, Y. Cancerella, J.-C. Mestries, J.-F. Kergonou. Biochem. Mol. Biol. Internat. 36 (1995) 733.

[107] G.L. Floersheim, N. Chiodetti, A. Bieri. Brit. .J. Radiol. 61 (1988) 501.

[108] G.L. Floersheim, A. Bieri. Brit. J. Radiol. 63 (1990) 468.

[109] G.L. Floersheim, A. Christ, R. Koening, C. Racine, F. Gudat. Int. J. Cancer 52 (1992) 604.

[110] J.M. Berg in "Metal Ions in Biological Systems. Zinc Fingers: The role of zinc(II) in transcription factor III A and related proteins." (H. Sigel and A. Sigel, Eds.), New York, Marcel Dekker Inc. (1989) 235.

[111] Y. Samuni, D. Coffin, A.M. DeLuca, W.G. DeGraff, D.J. Venson, I. Ambudkar, M. Chevion, J.B. Mitchell. Cancer Res. 59 (1999) 405.

[112] T. Ushakova, H. Melkonyan, L. Nikonova, V. Afanasyev, A.I. Gaziev, N. Mudrik, R. Bradbury, V. Gogvadze. Free Rad. Biol. Med. 26 (1999) 887.

[113] G.L. Floersheim. Brit. J. Radiol. 65 (1992) 1025.

[114] G.L. Floersheim. Radiat. Res. 133 (1993) 80.

[115] H.J. Koch. Radiat. Res. 135 (1993) 438.

[116] G.L. Floersheim. Radiat. Res. 135 (1993) 439.

[117] T. Elnimr, S.M. Abdel-Rahim. Biol. Trace Element. Res. 62 (1998) 25.

[118] M. Karbownik, R.J. Reiter. Proced. Soc. Exptl. Biol. Med. 225 (2000) 9.

[119] R.T. Blickenstaff, S.M. Brandstadter, S. Reddy, R. Witt. J. Pharm. Sci. 83 (1994) 216.

[120] Vijayalaxmi, M.L. Meltz, R.J. Reiter, T.S. Herman, K.S. Kumar. Mutat. Res. 425 (1999) 21.

[121] M. Karbownik, R.J. Reiter, W. Qi, J.J. Garcia, D.-T. Tan, L.C. Manchester, Vijayalaxmi. Mol. Cell. Biochem. 211 (2000) 137.

[122] R.T. Blickenstaff, S.M. Brandstadter, S. Reddy, R. Witt, K.B. Lipkowitz. J. Pharm. Sci. 83 (1994) 219.

[123] K, Schwarz, W. Mertz. Fed. Proceed. 20 Suppl 10 (1961) 111.

[124] A. Albert. Fed. Proceed. 20 Suppl 10 (1961) 137.

[125] S.K. Abraham, L. Sarma, P.C. Kesavan. Mutat. Res. 303 (1993) 109.

[126] H. Inano, M. Onoda, N. Inafuku, M. Kubota, Y. Kamada, T. Osawa, H. Kobayashi, K. Wakabayashi. Carcinogenesis 20 (1999) 1011.

[127] H. Inano, M. Onoda, N. Inafuku, M. Kubota, Y. Kamada, T. Osawa, H. Kobayashi, K. Wakabayashi. Carcinogenesis 21 (2000) 1835.

Received: December 7, 2001 - Accepted: December 20, 2001 Accepted in publishable format: December 21, 2001 